\title{
In piscibus diversis; the Bone Evidence for Fish Consumption in Roman Britain
}

\author{
By ALISON LOCKER
}

\begin{abstract}
INTRODUCTION
$\mathrm{T}$

This paper examines the fish-bone data from Roman sites in Britain. Earlier work collated the evidence from Iron Age sites around the North $\mathrm{Sea}^{1}$ and sites dating from the first to sixteenth centuries A.D. bordering the southern North Sea. ${ }^{2}$ Both of these studies included some Roman assemblages from Britain. For the rest of the country the data remained a dispersed collection of published and unpublished reports. This survey attempts to collate and examine all the evidence from fish-bone assemblages for trends in fish consumption nationally, regionally, and at different types of sites. The evidence for the Iron Age as described by Dobney and Ervynck indicated little and localised consumption of fish. Some trends, observed in a few assemblages, have been used to suggest wider implications for the Roman period, for example Nicholson has suggested there was little evidence for the consumption of deep-sea fish, such as cod and ling, in Northern Britain. ${ }^{3}$ The quantities of fish bones are generally much smaller for the Roman period compared with a few centuries later, when fishing for herring and cod became of such commercial importance. ${ }^{4}$

Collating these data was an opportunity to assess whether the cultural effects of the Roman invasion and subsequent occupation discernibly altered patterns of fish consumption in a manner distinct from preceding periods. There could be differences between areas or sites distinctly Roman, such as forts or towns, and native settlements. The indigenous population living close to forts and towns were most likely to absorb new and fashionable trends in food and culture, while other remote communities continued in an Iron Age tradition. By the fourth century most villa-owners were of British stock but had become integrated into Roman provincial mores. Similarly, many army officers would have been British strongly influenced by Roman culture, though with a British slant. Changes in culture affect what and how you eat, introducing new foods, cuisine, and meal structures. A mark of distinction and upward mobility, such changes may be visible from the range of fish species that were eaten, represented by surviving fish bones. King has shown evidence of Romanisation reflected in the changing proportions of cattle, sheep, and pig in bone assemblages across the Empire. ${ }^{5}$

However there are some intrinsic problems with Roman fish-bone assemblages; they are often relatively small, even where extensive sieving has been carried out. On sites where all the bone
\end{abstract}

Dobney and Ervynck 2006.

Enghoff 2000.

Nicholson 1993a.

Barrett et al. 2004.

King 1999. 
was hand-collected the recovery of fish bones is poor to non-existent, and biased towards larger species such as cod. In these circumstances the absence of fish should not be taken as a sign that fish were not eaten, just that they have not been found. However, where a systematic policy of sieving has been implemented and no fish bones have been recovered, it is probable that fish did not feature strongly in the diet. In some older excavations (pre-1970) no sieving was carried out. Today, while economic constraints restrict sampling to certain selected deposits, a programme of fine-screening to recover small fish species, along with other botanical and entomological remains, is standard practice and the great majority of sites included here were sieved. Before discussing these data, a number of secondary sources which reflect fish consumption should be also considered.

\section{SECONDARY SOURCES}

Indirect evidence for fish consumption is varied. Associated finds include particular types of amphorae which were used to transport salted fish and fish-sauce across the Empire. Fish sauces, used as a flavouring, were made from fermented small fish and intestines strained to make a sauce of varying quality and price. Morales describes garum as the best and muria as of medium quality. ${ }^{6}$ Liquamen was another variety, but there is some confusion over the differences between the three. The residue was sold as an inferior product, allec. ${ }^{7}$ These amphorae are sometimes stamped with the maker's name, place of origin, and contents, for example the name 'Lucius Tettius Africanus' from Antibes was inscribed on a first-century amphora containing six Spanish mackerel heads found in Southwark, London. ${ }^{8}$ Alcock cites finds of amphorae marked as containing fish from the Poultry site, London, possibly sent from Cadiz, and at Peninsular House, London, where amphorae were found in association with fish remains (described below). ${ }^{9}$ Imported fish-sauce amphorae have also been found at Chester, Colchester, York, and Gloucester and at a pottery works on the Isle of Grain, Kent, where amphorae were made and garum was shipped, but further reference to the latter site remains elusive. Larger salted fish were also shipped in amphorae, either whole or cut in pieces, as salsamenta.

Amphorae have been used to calculate the importance of fish products in the Empire. BekkerNielsen, reiterating Curtis that fish products have been overshadowed by wine, oil and grain in the study of ancient trade, concluded that in the early days of the Empire, at the height of garum production, combined fish products could have been the fourth most important commodity. ${ }^{10}$ Ejstrud compared the data for amphorae from five sites in Western Europe ${ }^{11}$ and the evidence supported the importance of the stored-fish trade within the Empire. Britain would have been no exception.

The remains of fishponds have been found at a few villa sites in Britain, such as Shakenoak. ${ }^{12}$ It has been suggested that they may have been intended to supply fresh fish rather than serve ornamental purposes. Fish farming was practised in Italy; Columella's commentaries ${ }^{13}$ show that marine fish, including bass, sea bream, wrasse and flatfishes, were kept largely as a show of wealth. Freshwater species were favoured by the less affluent. The scarcity of evidence from Roman Britain suggests fishpond culture was an élite occupation associated with very few villas,

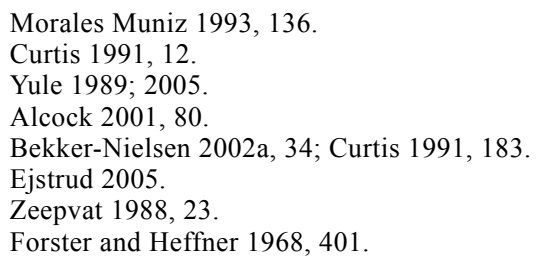


and there is no evidence for the fish kept in them. Anecdotal evidence from Rome indicates very high prices for certain species, reflecting the buyer's status. Some were kept as pets, including the infamous moray eel which wore earrings and a necklace and came to Crassus when called as described by Aelian. ${ }^{14}$ Traces of prehistoric fish-traps survive as wooden structures in Britain, for example of Bronze Age date from the Severn Estuary and Neolithic structures from the Isle of Wight and Hull. ${ }^{15}$ Medieval stone traps and weirs survive and are recorded in the literature. Columella ${ }^{16}$ describes the use of natural or enhanced rocky pools on the shore for keeping fish, using the tides to refresh the water, but there are no finds of Roman date from Britain. There is some material evidence for fishing gear, such as hooks, from sites including Fishbourne Palace and the fort at Corbridge. ${ }^{17}$

Literary evidence includes orders for fish-sauce found on writing-tablets from the fort at Vindolanda. ${ }^{18}$ Though not from Britain, Apicius' Artis Magaricae Libri X, a cookery book no longer attributed solely to Apicius (a first-century gourmet and cookery writer) but a fourth-tofifth-century compilation, includes recipes for ray, conger eel, eel, grey mullet, perch, sea bream, and scad. ${ }^{19}$ These fish could have been caught in British waters and would have been quite familiar to a Mediterranean palate.

The introduction of new cooking methods and cooking utensils to Britain would have impacted on culinary practices, including those for fish. Wilson describes types of frying-pans suited to cooking fish. ${ }^{20}$ These could also be used for other purposes, but the range of pots and pans indicates a sophisticated cuisine and many have been found at British sites. ${ }^{21}$ These finds are more likely to be associated with the Roman concept of a distinct kitchen space, rather than the Celtic way of roasting and boiling on a central hearth which would have continued unchanged in many native settlements.

There is little artwork reflecting fish consumption from Britain; fish in mosaics tend to be stylised, but their inclusion suggests they were valued. ${ }^{22}$ There are some mosaics from Rome and North Africa showing men fishing, and certain types of nets can be identified. ${ }^{23}$ Fishing is both from boats and the shore, suggesting it was not a lack of technology that prevented the capture of cod and other large offshore gadids in significant numbers.

Recent studies on isotopes extracted from human bone have been used to measure the consumption of marine resources in individual skeletons. Poundbury cemetery, near Dorchester, ${ }^{24}$ has provided some data for differing levels of fish consumption. Late Iron Age and early Roman burials contained plant and animal proteins, but no marine ones. Later Roman burials in mausolea and lead-lined coffins showed evidence of marine proteins, while contemporary burials in wooden coffins did not. This suggests that status may have been attached to fish and other seafood.

Of the secondary sources described above, the inscribed amphorae, orders for muria (fish-sauce) from Vindolanda, and the few remains of fish hooks are the most unequivocal secondary evidence of Roman influence on fish consumption in Britain. Isotope readings give some indication for varying consumption of marine resources in general. The rest are tangential, and for direct evidence it is necessary to examine the species and location of the fish bones themselves.

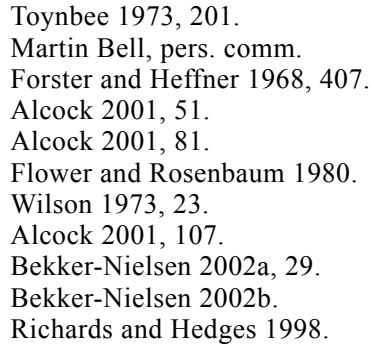




\section{METHODS}

A total of 8,796 bones were identified to species or family level from 109 sites grouped into seven regions: the North, Midlands, South/South-East, London (north of the Thames), East London Cemeteries (an atypical group kept separate), Southwark (south of the Thames and five miscellaneous sites), and the South/South-West. Although Britain was the area of study, all the sites, except one in Scotland, were in England with the addition of two 'native settlements' from the Isles of Scilly. The assemblages vary greatly from just one or two bones to over a thousand. No comparison has been made against the number of sites with animal bones, though Dobney and Ervynck found a slight increase in the proportion of Roman animal bone assemblages containing fish over those from the Iron Age in their area of study. ${ }^{25}$ However, the numbers of fish bones from many sites were very small.

The data were initially divided by site and date to the nearest century. This gave rise to nearly 40 tables, retained as an archive available from the author. Analysing data divided by date did not give significantly different results than treating each site as a single unit. The tables published here only show the latter. Fish bones were sometimes unquantified, but denoted as present. These are shown by '+' for bones or '*' for scales, marked beside the total or NISP (number of identified specimens). Scales were rarely identifiable to species, and if added to the NISP their numbers would give undue weighting to one species. While the NISP comprised the primary data, the lack of quantification of some bones and scales was problematic for comparing species and sites, as the NISP was often incomplete. To reconcile these anomalies the data have also been analysed by the number of occurrences between sites to determine the most important species. A species identified at a site counts as one occurrence, regardless of quantity, and the total number of occurrences for each species is shown in the extreme right-hand column of each table. This method also has the advantage over NISP of redressing the over-representation of small species, such as herring, which may have many identified bones but represents relatively little food compared with larger fish. Occurrence also tempers the 'eel effect', as eel have almost double the number of vertebrae of other fish. When ranking the most prolific species by occurrence in the graphs each has been expressed as a percentage of the total number of possible occurrences. This relationship is independent of other species, unlike the NISP percentage in which each is a part of the entire quantified assemblage. The NISP has been used to compare species within a site. At the base of each table, beneath the NISP totals, the number of species identified at each site is shown compared against the regional total. This gives an indication of diversity, influenced to some degree by the size of the assemblage. The majority of the fish were recovered from sieved samples, while some large bones were hand-collected. There were some sites where fish have been noted as present but not identified: the forts at Caernafon and Brecon from the early excavations by Wheeler in the 1920s, also Corbridge and Maryport referred to by Alcock and Davies. ${ }^{26}$

Eighty-two species and families of fish were identified. Table 1 lists them in family order, with an indication of habitat. Some family names have been used, for example the Cyprinidae (the carp family), for whom the most reliable species specific elements are the pharyngeal teeth. Other bones are difficult to identify beyond family level. Each site is listed in Table 2, with dates and references, and is assigned an identification number used in the regional tables along with the first three letters of the site name or the site code. Table 3 combines the data from each region and shows the overall occurrence for all sites. Tables $4-10$ show the data by site for each region.

FIG. 1 maps the location of each site, marked by number. FIGS 2-8 are all based on occurrence; FIG. 2 is the combined data; FIGS 3-8 indicate the key species by region, occurring at/or greater than 10 per cent.

25 Dobney and Ervynck 2006.

26 Alcock 2001, 48; Davies 1971, 129. 


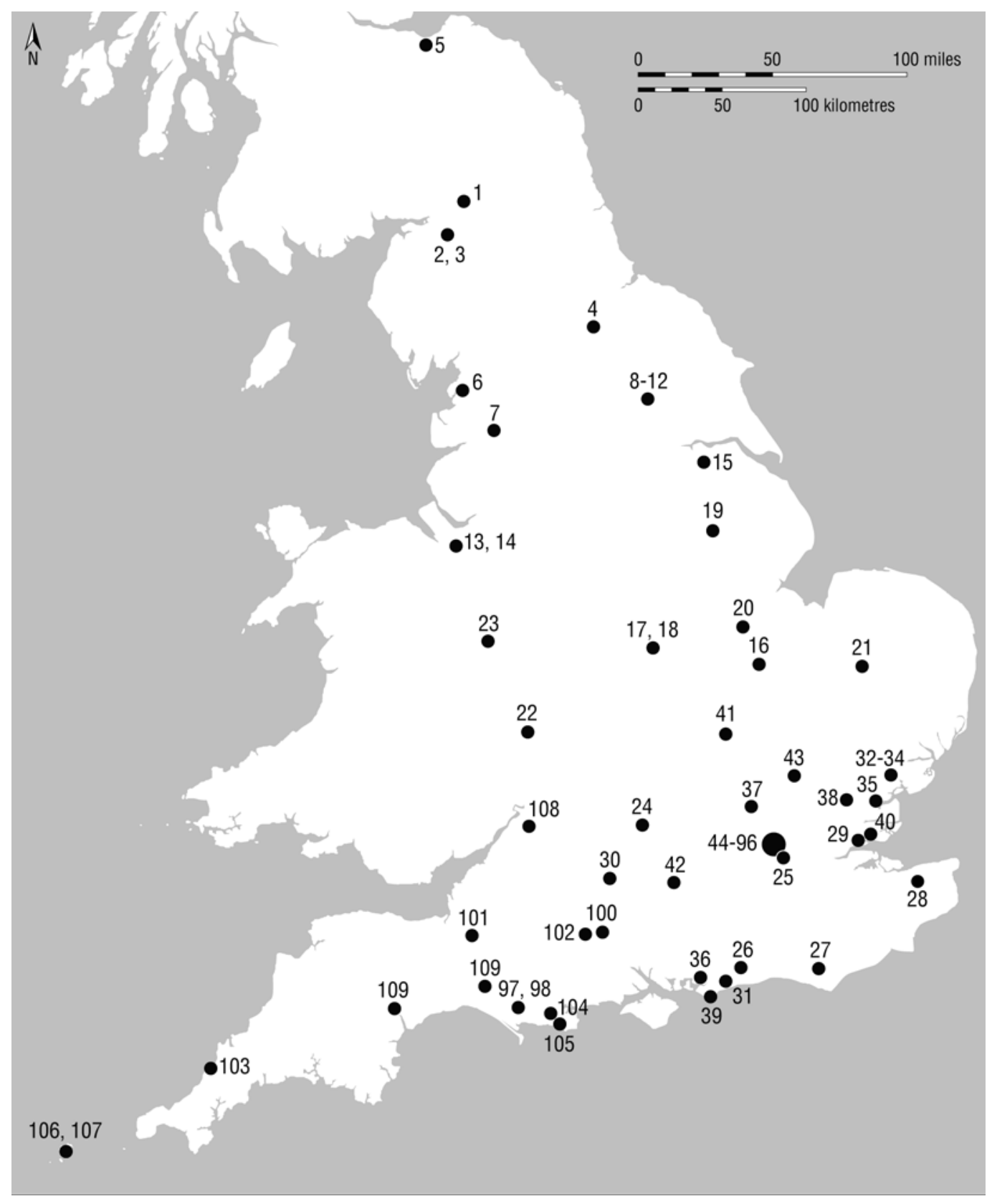

FIG. 1. Map showing location of sites with fish bone; for details of sites see Appendix, Table 2. (Drawn by H. Buglass) 


\section{THE DATA}

The combined data for all regions (Table 3) show that some species are very poorly represented throughout, others have a regional preference, often habitat-related, while some are predominant in all regions. FIG. 2 shows eel to be by far the most common by occurrence at 66 per cent (and also by NISP 31 per cent). The five most important species are eel, herring, plaice/flounder, cyprinid, and salmonid. Only cyprinids are exclusively freshwater; though eel and salmonid are caught in fresh water, they can also be caught inshore and in estuaries, as can flatfish and herring. The prominence of salmon was an interesting result, and is supported by the NISP data. Their bones are regarded as especially friable, affecting preservation, and skull fragments are rare. ${ }^{27}$ They are generally regarded as under-represented in bone assemblages.

Sample size influences the number of species that will be present, either by the volume of the sample itself and/or the number of contexts that are analysed, though there is not always a simple correlation between them. The largest sample is from London, which also had the most sites, 26. However only 40 species/groups were present, the same number as for the North and close to that for the Midlands, though both the latter were smaller in sample size and number of sites. The highest number came from the South/South-East with 48 species from 20 sites and a

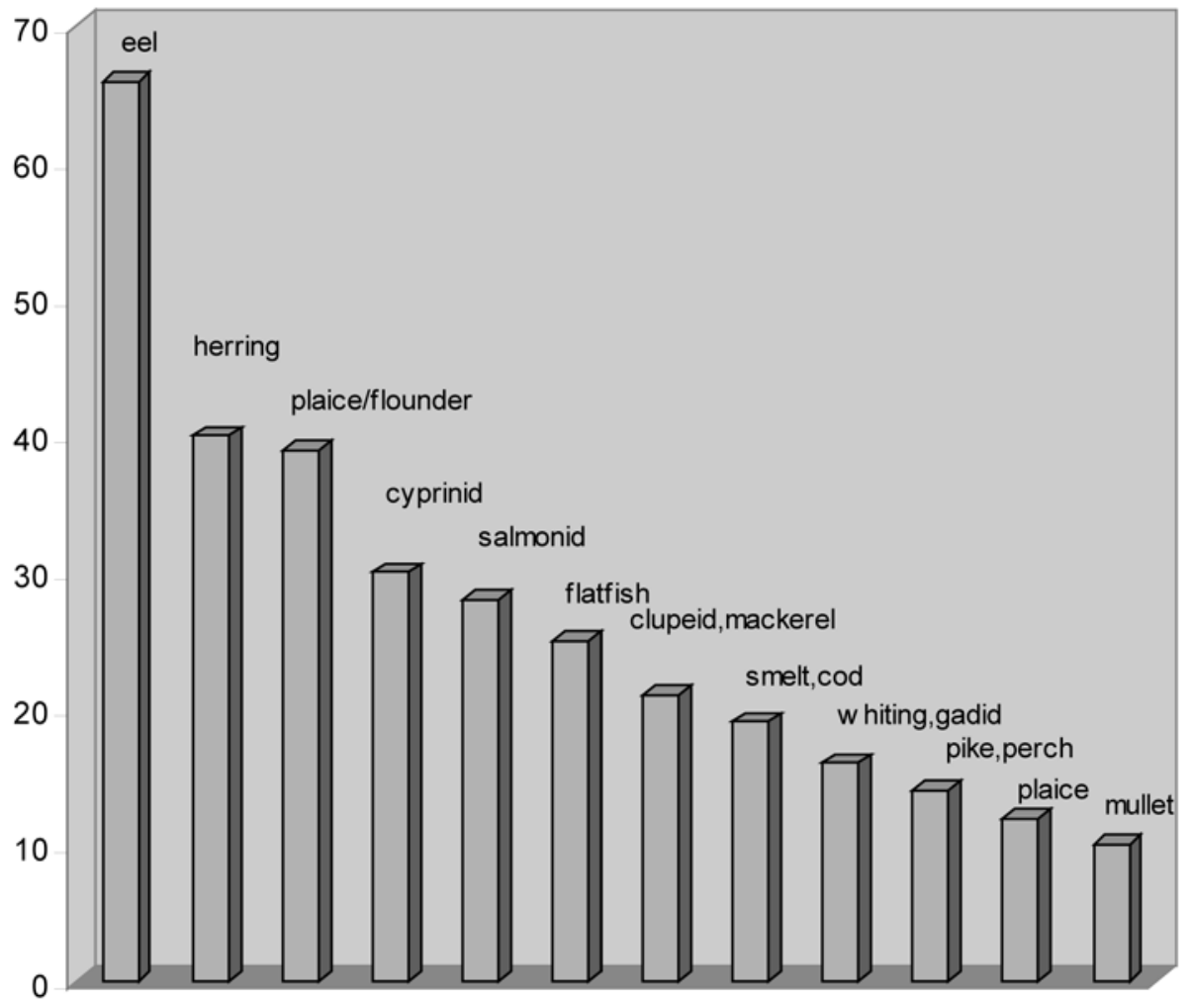

FIG. 2. Percentage of fish species from all sites. 
sample size only 67 per cent of that from London. These differences are also observable between individual sites, where a small assemblage has more species than a larger assemblage which may be more monospecific, often eel. This demonstrates that the data have a wide range of variables. Significant among these would appear to be the type of site and location; 85 per cent of the identified bones were of urban origin, including London and Southwark, where excavation and sampling has been more intensive and the deposits tend to have greater concentrations of organic material, reflecting a higher density of population. There follows a summary of the main features of the assemblage from each region. Site numbers, in brackets, follow the site names.

\section{THE NORTH (Table 4, FIG. 3)}

Carlisle $(2,3)$ and York $(8,9,10,11,12)$ contributed 98 per cent of the fish, even though the Bedern (8) and Skeldergate (11) in York were not quantified. The forts produced little bone; the salmonid vertebrae from Birdoswald (1) were probably hand-collected. Ribchester (7) was extensively sieved but produced few fish. There are no villa sites. All the sites are near the coast and estuaries except York, some 36 miles inland, which is reflected in the numbers of cyprinids and pike present. Only one site was north of Hadrian's Wall, Inveresk (5) near Edinburgh. The only possible evidence for imported fish is red mullet and wrasse from Catterick (4); although both can be found off the local coastline, they would be scarce.

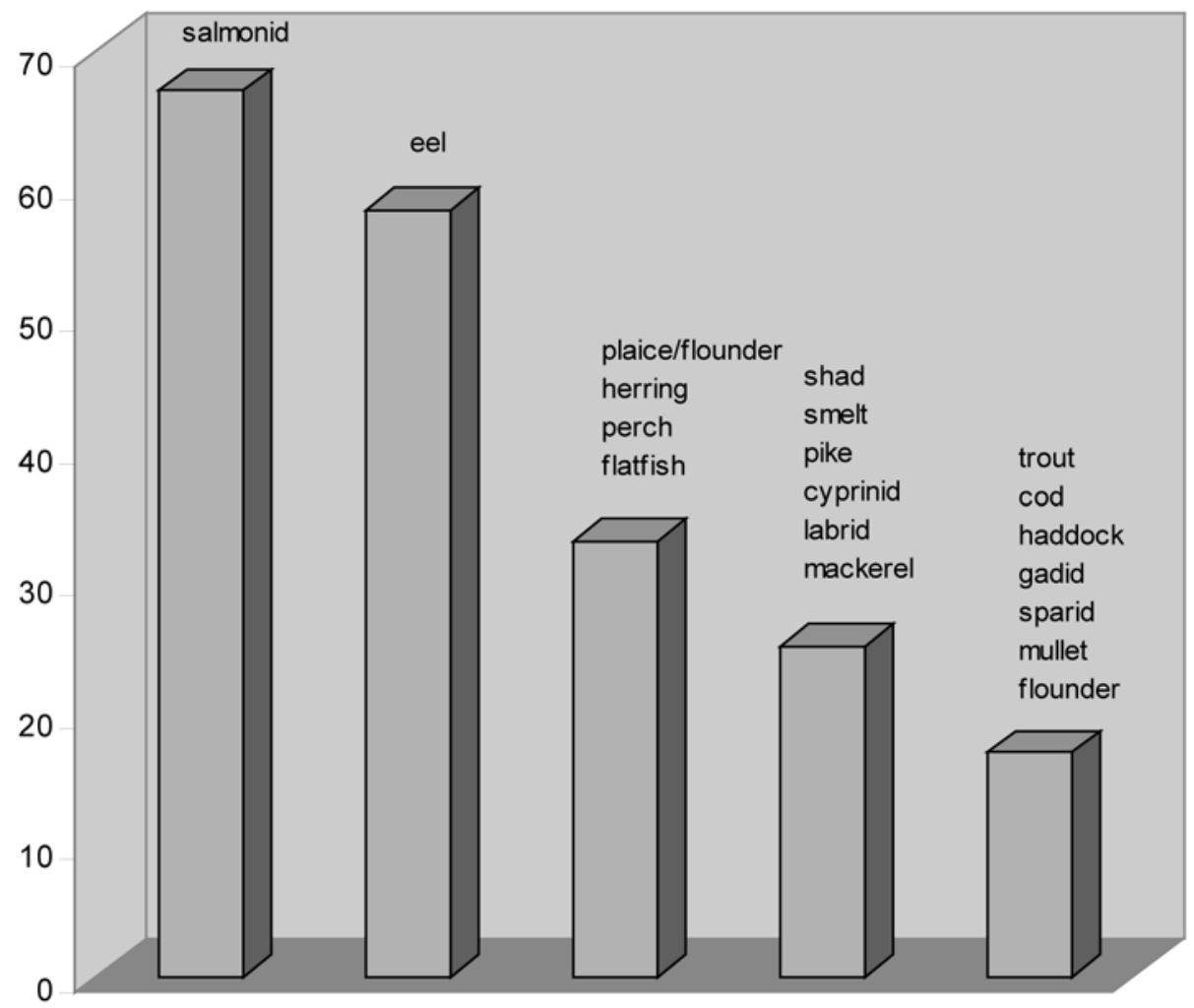

FIG. 3. Percentage of fish species from the North. 
Eel is numerous at both Carlisle and York, as are salmonids, particularly at Carlisle, where local rivers, the Eden and Esk, are still important for salmon today. ${ }^{28}$ The seasonal migration of smelt into rivers to spawn was exploited at York. According to Maitland and Campbell the Romans are supposed to have raised smelt in freshwater ponds, ${ }^{29}$ but they give no source for this information, and smelt are not found in the Mediterranean. Salmonids take first place by occurrence, as shown in FIG. 3, followed by eel. This is the only area where salmon is the most commonly occurring fish. Flatfishes, plaice/flounder, herring, and perch share third place. Gadids, both large and small, are poorly represented in this region. Not included in the table, for reasons of poor dating, is a single deposit from St Mary Bishophill, York. ${ }^{30}$ Described as thirdto tenth-century, it may not be Roman. However this unusual assemblage deserves mention as it was composed of the bones of herring, sprat, and non-specific small clupeids. It is typical of the type of deposit attributed to the domestic manufacture of fish-sauce, which has also been identified from Lincoln and London.

THE MIDLANDS (Table 5, FIG. 4)

Towns contributed most of the fish, 96 per cent by NISP. The biggest assemblage, Causeway

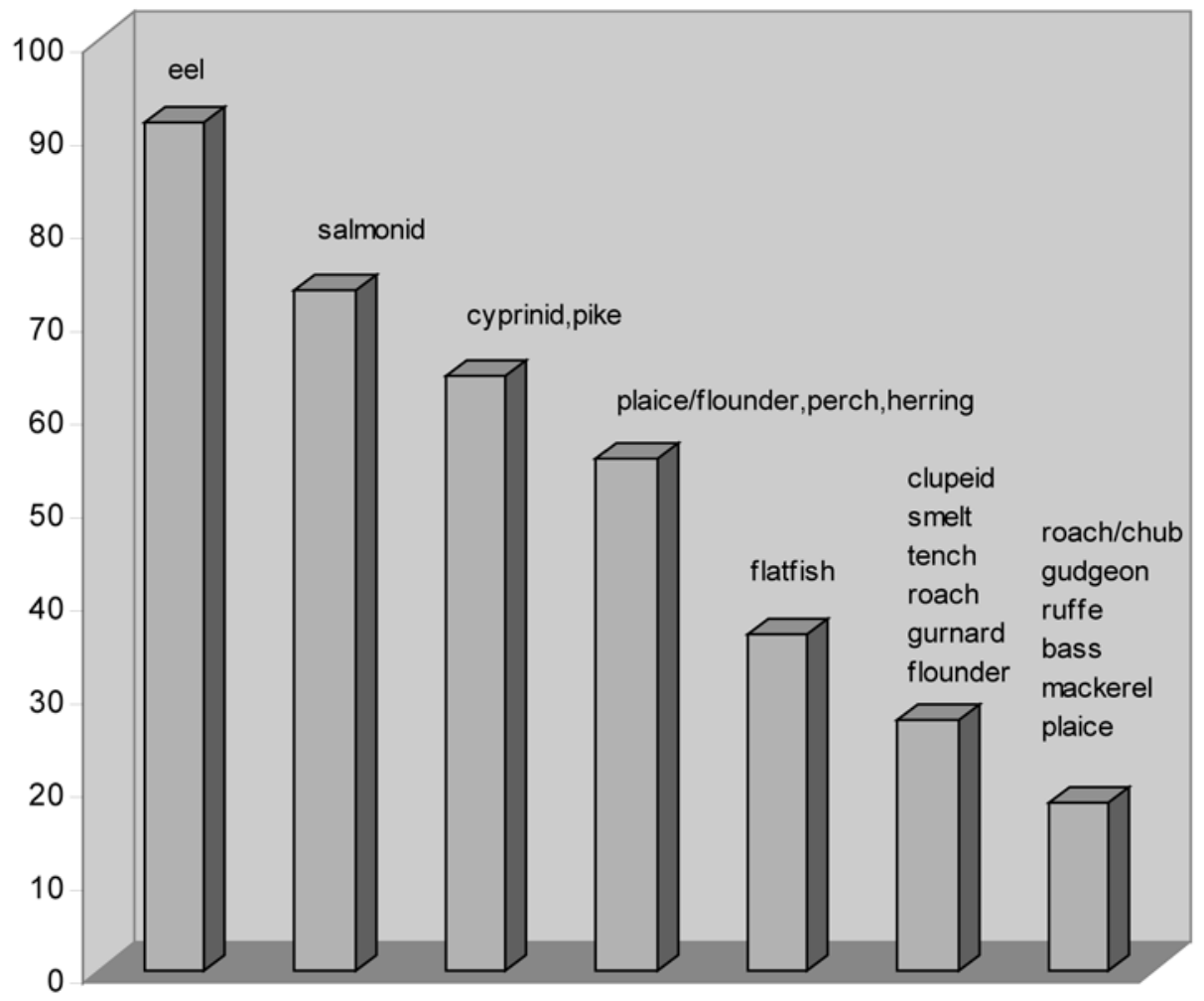

FIG. 4. Percentage of fish species from the Midlands. 
Lane, Leicester (18), was 48 per cent eel by NISP, whereas at Lincoln (19) cyprinids were most common, also 48 per cent. Here, as well as the quantified fish, sand-eel and small clupeids (herring and/or sprat) were found in very large numbers in quayside deposits. A sub-sample of $458 \mathrm{~g}$ represented an estimated 2,860 individuals. These small fish may be another example of the domestic manufacture of garum or allec, though other interpretations have also been considered. ${ }^{31}$ The assemblage from the baths-basilica at Wroxeter (23) was dominated by salmon ( 37 per cent), perch ( 27 per cent) and pike ( 25 per cent), probably all caught in the River Severn. There may be some bias towards larger species here, as the fish were recovered by handcollection, dry-sieving to $5-10 \mathrm{~mm}$, and very limited wet-sieving. Although 50 miles from the sea, marine fish — bass, thin-lipped grey mullet, plaice and mackerel — were identified; they may have been brought there salted (salsamenta), or possibly fresh, as discussed below.

Imported species include the Nile catfish spine from the settlement at Dragonby (15), which may have been traded as a single bone. Spanish mackerel was found at Chester (13). The identification of carp (Cyprinus carpio) from Lincoln (19) on the basis of a serrated spine, some several centuries earlier than other examples of this fish in Britain, is more safely attributed to barbel, a native species with similar spines, as suggested by Ervynck. ${ }^{32}$ Bitterling, also identified from Lincoln, is more usually regarded as an introduced species, though native to Central and Western Europe including France. ${ }^{33}$ FIG. 4 shows eel dominant in the Midlands and found in all sites but Wroxeter (23), possibly a factor of the recovery methods at the latter site. Eel is followed by salmonid, then cyprinid and pike, plaice/flounder, perch, herring. This suggests a strong reliance on freshwater fisheries.

\section{THE SOUTH AND SOUTH-EAST (Table 6, FIG. 5)}

In contrast to the North and the Midlands, only five of the twenty sites are from towns; the latter produced only 40 per cent of the fish bones. Villas had 49 per cent and other rural sites 11 per cent. This area also had the largest number of species, though not the greatest numbers of sites, or largest sample size. For the region, eel occurs in 70 per cent of all sites, followed by herring and flatfishes (largely plaice and flounder), common in the shallow waters and estuaries of the southern North Sea. From the towns, Canterbury (28) has a small NISP sample, largely flatfish. The colonia at Colchester is represented by three sites, the largest being Culver Street (32), where eel and herring feature strongly as well as flatfishes and mackerel. Cod, haddock, whiting, and indeterminate gadids were present in small numbers. The inland position of Silchester (42) was reflected in the presence of eel, pike, and cyprinids, but the assemblage also included marine fish - bass, scad, mullet, and wrasse.

The prime high-status rural site of the region is Fishbourne Roman Palace (36). However there is no evidence for either imported or very large fish to denote wealth. Bass could have been caught locally on the South Coast, but may have had some significance in this particular context. Ingrem has suggested a possible feasting episode for these fish remains which were found in a single deposit. ${ }^{34}$ The most inland of the villa sites was Castle Copse (30), about 50 miles from the nearest coastline; the assemblage included eel, salmonids, and trout, but few cyprinids. There were also marine fish - bass, scad, sea bream, and flatfishes. Popular in the Mediterranean, bass and scad could also be caught on British southern coastlines. As at Silchester the state of these marine fish would determine their status, to be discussed below. The fish from Gorhambury villa

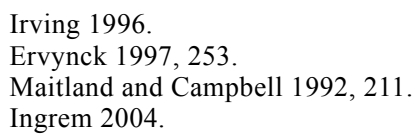




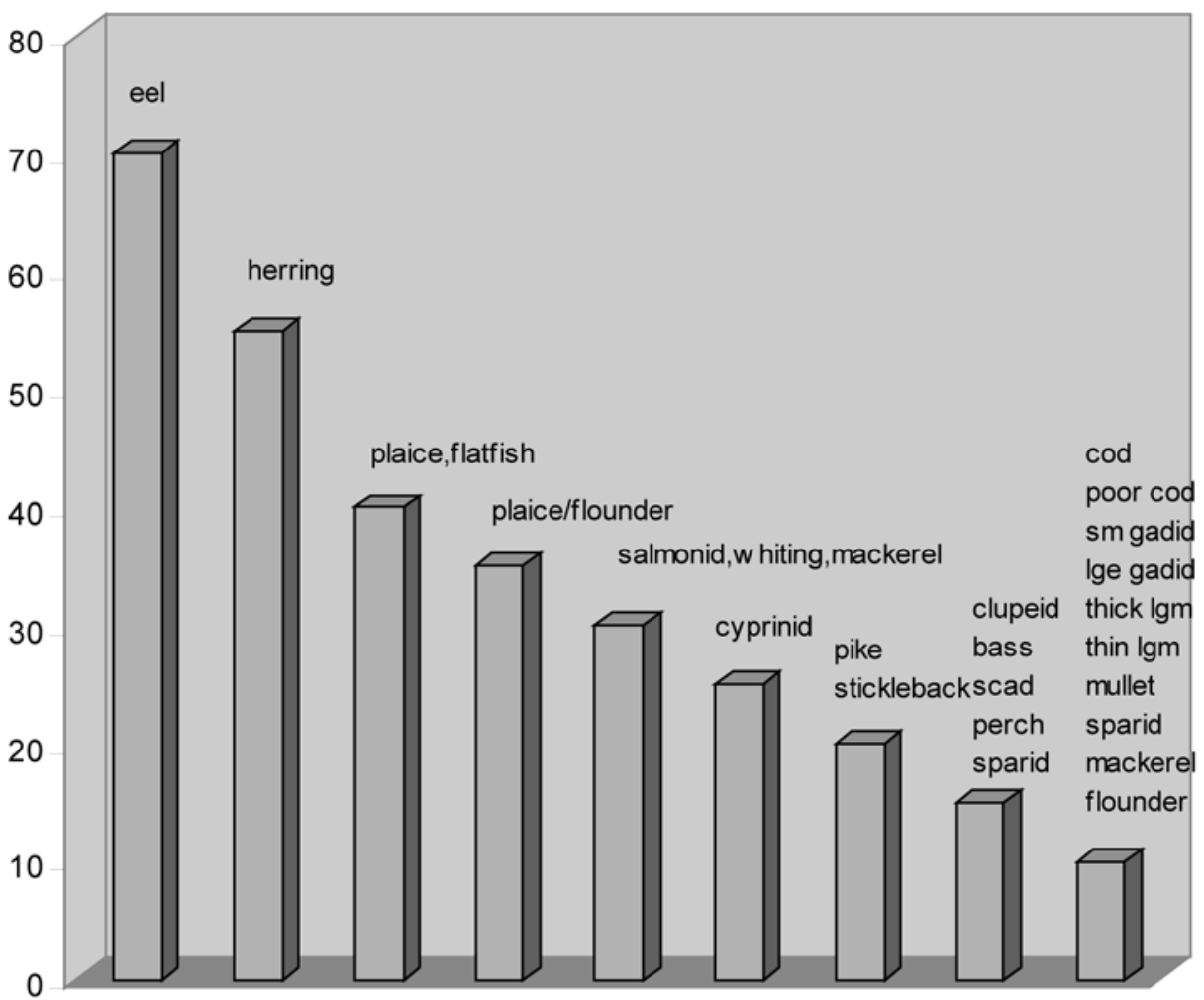

FIG. 5. Percentage of fish species from the South/South-East.

(37) were largely eel, but also included mackerel, and possibly Spanish mackerel. Great Holts Farm (38) is a late Roman farm and villa where imported plants and possibly livestock were of Mediterranean origin. The small assemblage of fish was typically local - eel, herring and flatfish, but also included Spanish mackerel and scad. Elm Farm (35), close to the Blackwater Estuary, also fits this 'locally available but with Mediterranean flavours' pattern, with mackerel and grey mullet among the fish present. Both Great Holts Farm and Elm Farm, though classified as rural settlements, seem to emulate the villa sites, reflecting the 'Romanisation' of native settlements. Spanish mackerel was identified from a Late Iron Age well deposit from Skeleton Green (43), an oppidum, in an assemblage otherwise of local origin and included here as an example of early Roman contact, completely atypical of other Iron Age assemblages. This species is on the edge of its range off the South-West coast and, in accordance with Enghoff, ${ }^{35}$ is regarded as imported in these assemblages. In contrast Barton Court Farm (24) is typical of a settlement where fish are poorly represented and only by those available locally, in this instance from fresh water.

LONDON (Table 7, FIG. 6)

The largest sample and number of sites came from this group. The largest assemblage, also 


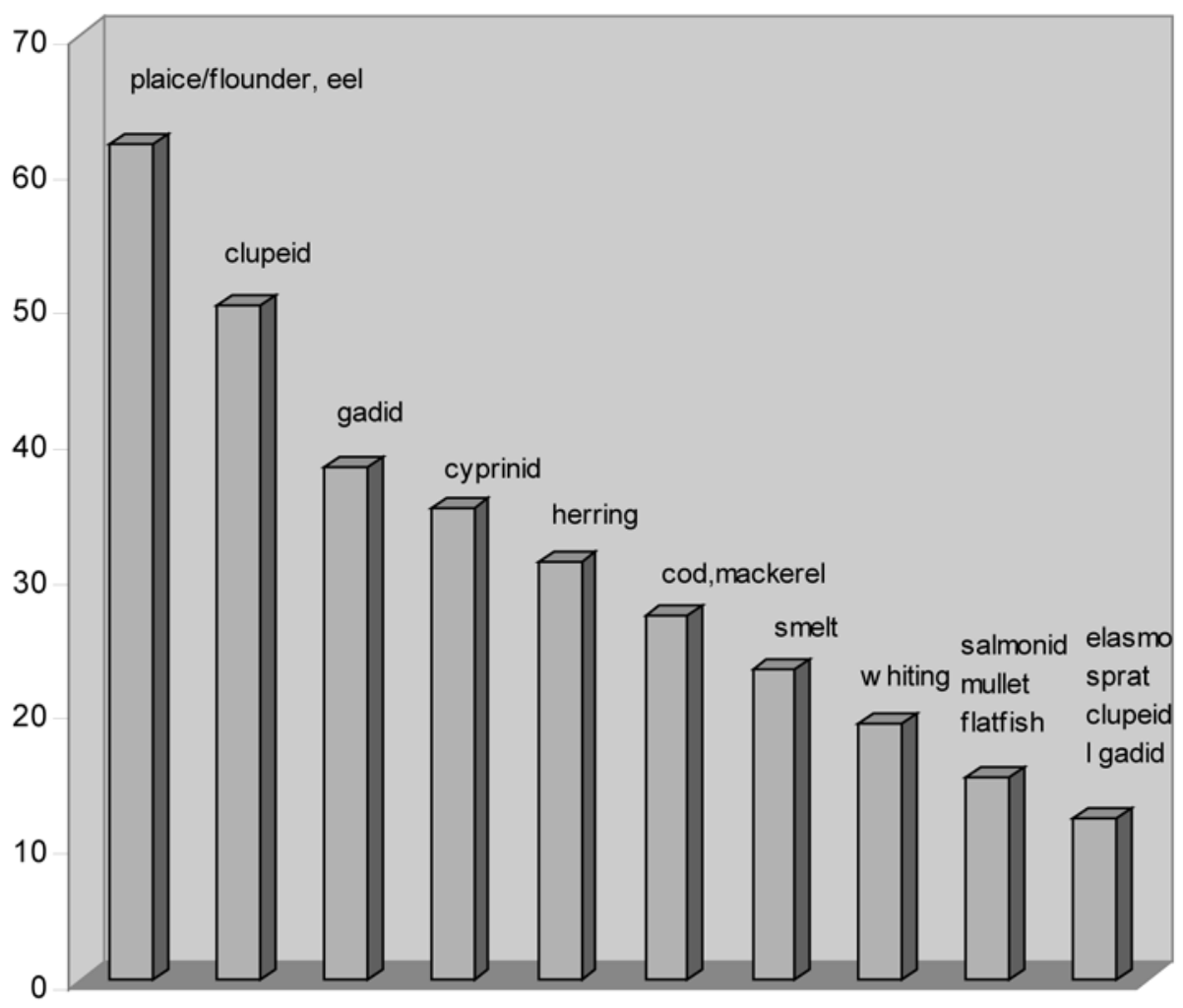

FIG. 6. Percentage of fish species from London.

showing the greatest variety of species, was from 17 Fish Street/Monument Street (59), which influenced the composition of the entire group of 26 sites, many of which had few fish bones. This unusual deposit, a well re-used as a rubbish pit, may be associated with an inn ${ }^{36}$ and contributed 57 per cent by NISP of the London sample. The variety of species included eel, salmonids, various cyprinids, perch, bass, grey mullet, and flatfishes. The ranking by occurrence seen in FIG. 6 , balances the influence of this site on the group. The importance of flatfish (particularly plaice/ flounder) and eel is evident, and also fisheries for herring and smelt. Cod is most prominent in this region at 27 per cent, and could have been locally caught in the southern North Sea. There is one unique find of at least three cods heads in a single 'scoop' deposit contemporary with a cemetery at 2-5 Devonshire Square (49), possibly an offering. The fish from Peninsular House (65) have not been quantified as the assemblage was composed of such a large deposit of young herrings and sprats that it was sub-sampled: as many as 6,000 individual herrings and 1,500 sprats were estimated for $1 \mathrm{~kg}$ of residue. The associated presence of CAM 186 amphora sherds, used to export fish-sauce from Southern Spain, together with some structural remains, suggest the domestic manufacture of this commodity.

Salmonids feature poorly; fewer here and in Southwark than any other region, although there were salmon fisheries in the Thames until it became too polluted. Wheeler considered that 
salmon, although common enough to support fisheries, were never particularly abundant in the Thames, a lowland river with few suitable spawning grounds compared to rivers rising in more upland areas. ${ }^{37}$ The Thames also had a rich indigenous fish fauna which would compete with salmon. There is no evidence from these assemblages for imported fish; the species all suggest localised exploitation of the Thames, its estuary, and the inshore waters of the southern North Sea. Fish-sauce was being produced locally, possibly as a cheaper alternative to the imported varieties.

\section{EAST LONDON CEMETERIES (Table 8)}

This small group of eight sites has been considered separately and the data have only been tabulated. The fish are all associated with cremations. Some bones are burnt and all are sufficiently linked to both urned and unurned deposits to suggest that they were part of the funeral ceremony. ${ }^{38}$ All the fish are small; herring and eel are most common by both occurrence and NISP. They could have been caught locally and there may have been some preference for small fish.

SOUTHWARK (Table 9, FIG. 7)

These sites are all south of the Thames, with some miscellaneous exceptions from East London.

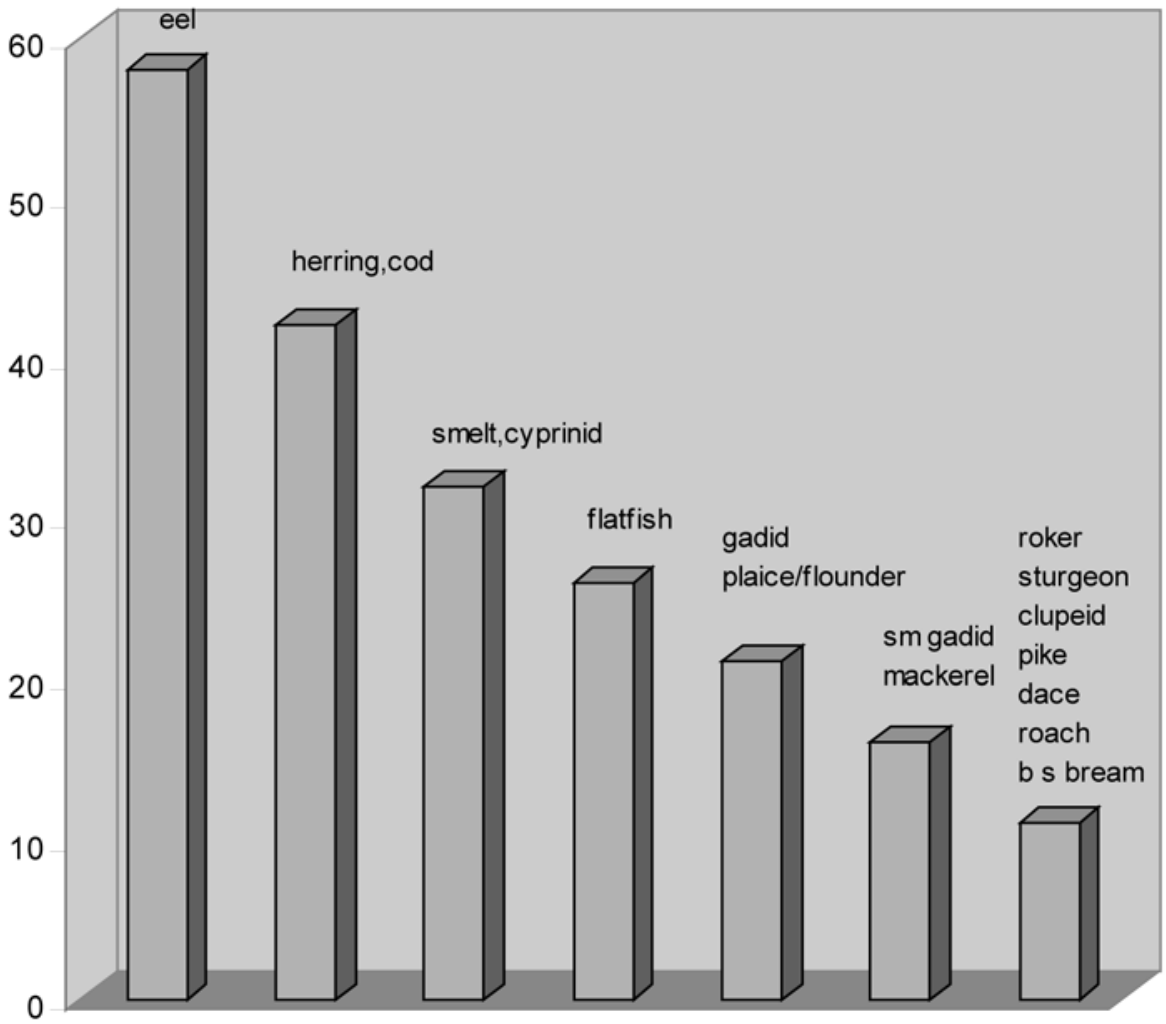

FIG. 7. Percentage of fish species from Southwark.

37 Wheeler 1979, 51.

38 Kevin Rielly pers. comm. 
Sites 84, 87 and 94 are along the Highway near Shadwell and Sites 86 and 90 are beside the Roman road to Colchester. None of these produced much fish bone. The size of the sample is small, and one site was not quantified. 31 species/families were identified, comparatively high against the NISP total. 57 per cent of all fish bone came from Fennings Wharf (83), mostly eel, herring, smelt and some indeterminate gadids but only eleven species. However three other sites with a low NISP count showed a relatively high level of diversity, notably Babe Ruth Bath House (84), where 8 species were identified from 11 bones, Parnell Road (90), 8 species from 16 bones, and Union Street (95), 12 species from 31 bones. This suggests variety, if not quantity. The fish from a second-century well at 1-7 St Thomas' Street (92) were not quantified but included small fish - eel, herring, smelt, and a variety of cyprinids, all of which could have been caught in the Thames. An example of imported salsamenta was found in first-century deposits at Winchester Palace (96). Six Spanish mackerel heads were found in an amphora marked as originating in Antibes.

Although many of the fish identified from Southwark were small species, it is notable for the only Roman finds of sturgeon, from Hibernia Wharf (85) and Union Street (95), in third-century deposits. It is surprising that more have not been found; the large distinctively-patterned scutes and spines are easily recognisable and big enough to be hand-collected, compensating for the poor preservation of the cartilaginous skeleton. This fish was highly regarded and, according to Athenaeus, served accompanied by music at Roman banquets. ${ }^{39}$ Sturgeon would have been the largest and most distinctive migrant visiting the Thames.

\section{SOUTH AND THE SOUTH-WEST (Table 10, FIG. 8)}

This group is the most regionally distinct with regard to the most common species. It also has the least diversity (excluding the East London cemeteries), despite having the third largest NISP. Most of the bone came from towns (88 per cent), in particular Dorchester. The fish from County Hall (97) were largely eel with some cyprinids, in contrast to Greyhound Yard (98), dominated by bass, wrasse, mullet, and sea bream. The latter is much more typical of fish assemblages from the South-West, compare the much smaller sample from the settlement site at Newquay (103). Other settlement sites at Ower (104) and Rope Lake (105) produced little bone. The two sites on the Scillies $(106,107)$ showed exploitation of locally-abundant species: sea bream, wrasse, and grey mullet. Both sites had gadid species: whiting and pollack. Fish from the Uley shrines (108) include bass, bream, and grey mullet, which, in this context, may have religious significance. Salmon, the most numerous fish, could have been caught in the Severn Estuary; they are still found there today and in many other rivers locally, though their numbers have been affected, as elsewhere, by pollution and the alteration of watercourses. ${ }^{40}$ Waddon Hill (109), the only fort, had few fish bones. Gadid, bass, and wrasse are referred to in the main report, but were not fully quantified and only shown as present in the table.

Apart from eel, FIG. 8 is dominated by wrasse (labrid), bass, sea bream (sparid), and mullet. These are all common off the south-west coast, as is conger eel — all familiar fish to both Romans and the indigenous population. Salmon fisheries operated not just in the Severn but also along the south-west coast during the mediaeval period ${ }^{41}$ and may well have been in use in Roman times. Freshwater fish are not well represented, except cyprinids from County Hall Dorchester (97).

39 Vissler 1991, 225.

40 Ayton 1998.

41 Fox 2001, 60. 


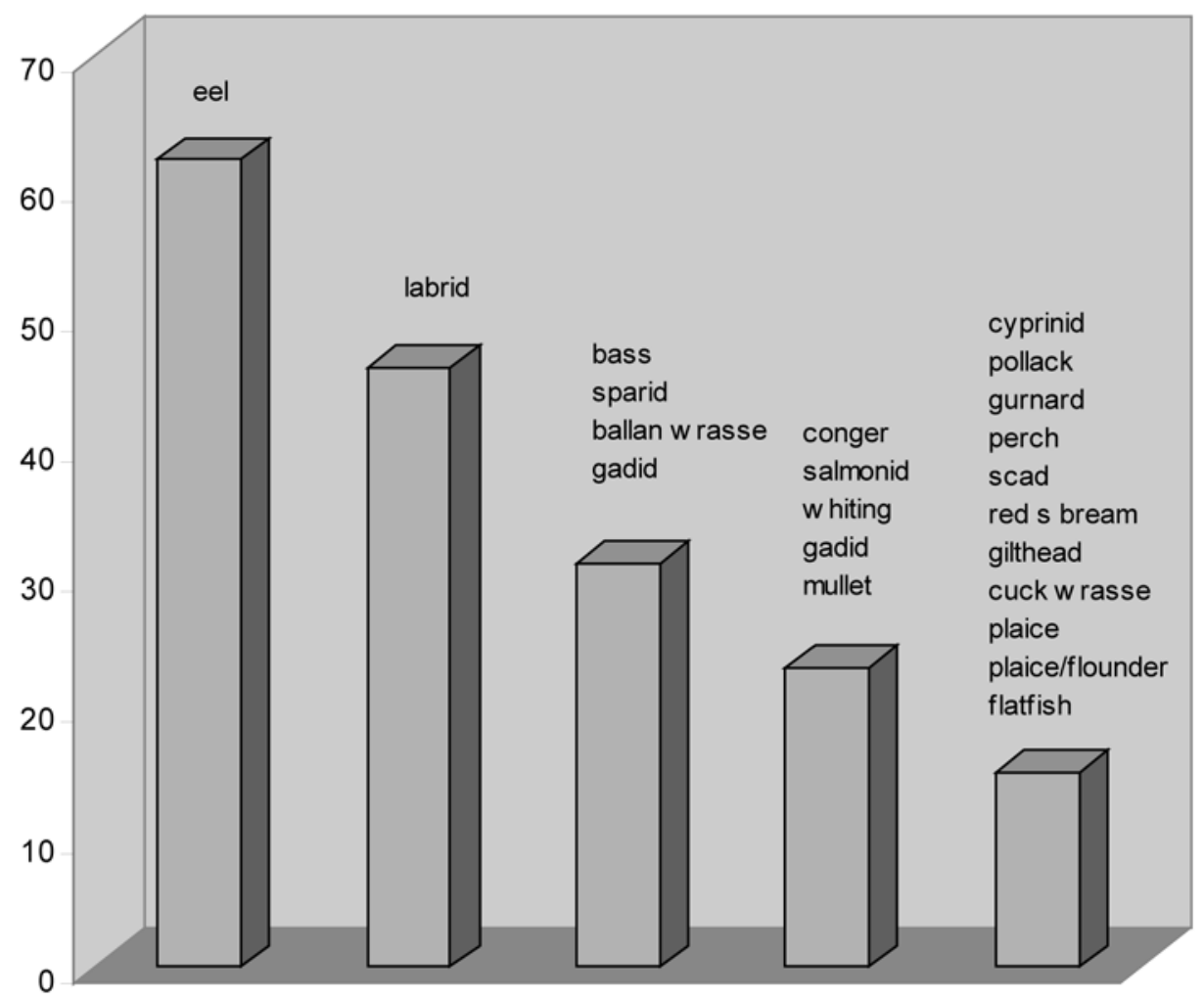

FIG. 8. Percentage of fish species from the South/South-West.

\section{DISCUSSION}

King's analysis of cattle, sheep and pig as indicators of dietary change in the Roman Empire found dietary regions were determined by the province, climate, and topography, but also influenced by changing cultural preferences. ${ }^{42}$ In Britain this is shown by a rise in beef consumption, whereas in the Iron Age sheep had been more prevalent. The force behind change was the presence of the Roman army, resulting in a 'Gallicization or Germanization of the diet'43 — particularly evident in military sites and towns. Change within the relative consumption of three major meat species is a much more discernible sign of Roman influence than changes in the pattern of fish consumption, a far smaller component of the diet. Dobney and Ervynck suggested that the role of fish at Romano-British native settlements was similar to that at their Iron Age counterparts, and was not greatly influenced by Roman traditions. ${ }^{44}$ Low levels of fish consumption were influenced by economic and subsistence issues and a negative cultural perception of fish. Roman sites showed evidence of developing freshwater fisheries and, to a lesser extent, estuarine and inshore marine fisheries, particularly those associated with high status. The findings here broadly support their

\footnotetext{
King 1999.

ibid., 189.

Dobney and Ervynck 2006.
} 
conclusions, though in the South/South-West, apart from the ubiquitous eel, inshore marine and estuarine fishing is more important than freshwater.

Each regional assemblage shows distinctions from the overall sample. The predominance of certain types of sites, proximity to towns, coastlines and rivers are all determining factors for fisheries and marketing. The high proportion of fish bones from urban excavations is not only influenced by population density and corresponding accumulation of waste, but rising numbers of excavations in advance of modern redevelopment projects. In the North, the Midlands, and the South/South-West fish from towns dominate the sample. The sites in London and Southwark are all from urban development. King showed that evidence of Romanisation was greatest at legionary and military sites, then towns and villas, being least at rural settlements. ${ }^{45}$ Fish bones are most abundant from Roman towns, many of which had a military presence. The only evidence for garum-production is from towns and late in date. The height of production was during the early Empire, so this may be a response to local demand no longer being met by imported goods. At native settlements fish are few and of local origin. ${ }^{46}$

All the villa sites with fish assemblages are in the South/South-East where there are also other rural settlements with fish bones. In some cases the cultural distinction between villa and farm is blurred. The late Roman farm at Great Holts Farm (38) had imported plants and possibly cattle, but no luxury fittings in the villa, such as mosaics. ${ }^{47}$ The only indication of Romanisation in the fish assemblage is Spanish mackerel and this site may reflect indigenous aspirations rather than a Roman owner. An inland settlement continuing in an Iron Age tradition, with few and only locally-available fish, is exemplified by Barton Court Farm (24) where there were only local freshwater species. Marine fish could have been brought to Barton Court as they were to Castle Copse (30), but they may have been unaffordable, or even undesirable, reflecting a different attitude to fish.

The villas, being in the South/South-East, are well placed for contact with the latest imported goods. However, although categorised as high-status sites, any supporting evidence from the fish is limited. Finds of Spanish mackerel, regarded as imported 'salsamenta', are few: Gorhambury villa (37), Skeleton Green (43), Winchester Palace (96), and Chester (13). None were found in the South-West, whose coastline marks the northerly extent of Spanish mackerel as a summer visitor, ${ }^{48}$ supporting Enghoff's view that it is imported in Northern Europe. ${ }^{49}$ The frequency with which this species has been identified across the Empire has devalued any status. Van Neer and Ervynck cite them as the major salsamenta species identified in amphorae, along with sardines (Sardina pilchardus). ${ }^{50}$ When a food becomes common it loses status, unless further defined by quality and price.

Finds directly associated with fish-sauce are scarce compared to those from around the Mediterranean. ${ }^{51}$ Common in Britain are amphora sherds of the types used for salted fish and fish-sauce, some of which are summarised by Alcock. ${ }^{52}$ The domestic production of fish-sauce suggests strong demand; the best evidence is from Peninsular House (65), London, with a large assemblage of small fish and associated evidence of amphorae and structural remains. Local fish-sauces were also made in other parts of the Empire, ${ }^{53}$ including a quality kosher version at

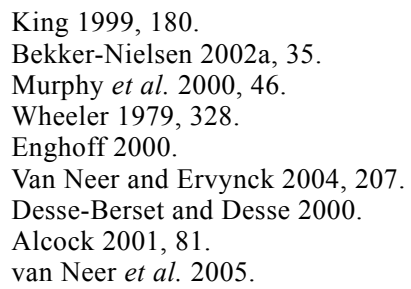


Masada in the Judean desert. ${ }^{54}$ Some local varieties may have been cheaper than importing from the industrial-scale installations on the Mediterranean coast, notably in Spain and North Africa and up into the Black Sea.

The overland transportation of fish could have been as efficient as during the mediaeval period, before the improvements that accompanied increasing industrialisation. Roads would have been the quickest route using wagons, while on trackways pack-horses were used. Boats could also deliver fish on inland waterways, with many more navigable than they are today. Moving stored fish was a comparatively leisurely activity, fresh fish were more urgent. Away from the coast there were a number of choices; fresh fish from local rivers and streams, deliveries of stored fish, fresh marine fish brought in quickly, or even live fish, though there is no supporting evidence for the latter.

The delivery of fresh marine fish to all parts of Roman Britain is a realistic proposition. Hoffmann cites a $150 \mathrm{~km}$ zone for the delivery of fresh marine fish in preindustrial Europe. ${ }^{55}$ Any site in proximity to a Roman road linked to a port could have fresh marine fish delivered, particularly during winter. The Roman road system was as good as any in mediaeval Britain. Fresh marine fish would have been a particular sign of high status at the most inland sites such as Castle Copse (30) and Silchester (42). Fish were successfully transported live during mediaeval times; species tolerant of low oxygen (eels and carp) were packed in wet straw and moss, while others were moved in barrels of water. As well as freshwater fish, bass, sea bream and grey mullet (all tolerant of low salinity) could also have been kept in ponds, at least for a short time. They would be exclusive and luxurious, defined by the expense of their transportation. Marine fish were kept in ponds in Italy and were fashionable among the élite, but in Britain this is speculative. The few ponds that have been found could have been ornamental and solely used for freshwater fish.

The eel was ubiquitous, but other species showed more specific distributions. Salmon occurred at many sites, particularly in the North and also in the Midlands, and some sites, such as Wroxeter (23), had comparatively large quantities of bones. The river systems with 'salmon runs' are mainly on the West coast of England, the Welsh coast, the North-West, and much of the Scottish coast. ${ }^{56}$ They have traditionally been caught by a variety of nets and traps in rivers, estuaries, and along the shore, with similar simple constructions in use since prehistoric times. Perhaps because of the mystery of migration, salmon were revered by the Celts as a sign of wisdom, associated with a severed stone head cult, wells, and streams. ${ }^{57}$ Salmon was also regarded as a Celtic totem animal ${ }^{58}$ and, according to Matthews, ${ }^{59}$ appears more often than any other creature in the Celtic world. A bronze of a fisherman hooking a salmon was found at Lydney Park, a temple to Nodens on the banks of the Severn ${ }^{60}$ - a river with a long history of salmon fishing, which probably supplied the Uley shrines (108), where salmon may have had a continuing iconic value. Similarly the migration of eels may have ensured the totemic status of the eel among the Celts, while not prohibiting its consumption. Both these fish are rich in calories and important nutritionally. ${ }^{61}$

The prominence of flatfishes, particularly plaice and flounder, in all regions is a reflection of their distribution around the coastline where they were easily caught in shallow waters, on

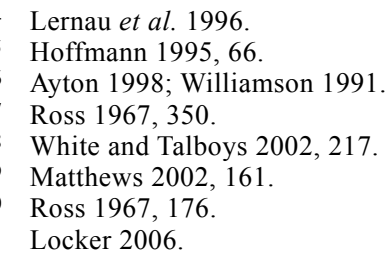


shorelines and in estuaries in tidal traps. Of the flatfishes only halibut and turbot might confer status. Halibut was identified from Elm Farm (35), a small immature individual. Turbot was identified from Canterbury (28), Fish Street, London (59), and Exeter (99). These large and prestigious flatfish have only been found in Southern England in this period. Halibut is not found along the Mediterranean coastline, but turbot is common, so the cooking of large flatfishes would have been known, using the Roman cooking-pans introduced to Britain.

Herring, sprats, and shad are all members of the Clupeidae; their oily flesh was utilised in all regions. Young herring was favoured for domestic fish-sauce manufacture in Britain, and may have been salted in this period, having the same qualities as mackerel, tunny, and many other oily fish of this family (Scombridae) found in the Mediterranean. The Gadidae, or cod family, do not seem to have been greatly exploited. This is not attributable to a lack of offshore, deepwater fishing either technologically, as mosaics have shown, or biologically, as the fish move seasonally inshore. Cod has the highest occurrence of all gadids, particularly in London and Southwark, though absent in the Midlands and the South/South-West. Cod is only found in assemblages from towns and the greater occurrence from London and Southwark may suggest a small, localised increase in demand compared with previous periods.

Freshwater species include the large family of cyprinids of which roach, dace, and chub were the most commonly identified. Perch and pike were also important, particularly in the North and Midlands. In London in the large assemblage from Fish Street (59) 46 per cent of the sample was cyprinid; the most common species were roach and dace, although the majority could not be determined above family level. In London perch was only found at this one site, no pike were identified. The Romans seem to have valued marine fish over freshwater; Alcock cites Diocletian's price edict of A.D. 301 for best quality marine fish being double the price of river fish. ${ }^{62}$

The fish 'familiar to a Roman palate', found in the Mediterranean, as opposed to those known to enlisted troops from more northerly parts of the Empire, include bass, sea bream, wrasse, mackerel, red and grey mullet. Also found off parts of the British coast, these fish were common in local fisheries, particularly in the South-West, as reflected in the assemblages from Dorchester (98), Newquay (103), and the Scilly Isles $(106,107)$. Whether these species were more favoured during the Roman period than previously on mainland Britain is debatable, given the few preRoman assemblages for comparison, though it does seem likely. On the Scilly Isles prehistoric collections suggest these fish were always abundant and exploited, a response to a remote environment where marine resources were vital. ${ }^{63}$

\section{CONCLUSIONS}

Evidence of 'Romanisation' in Britain from fish assemblages is tenuous. There are no clear indications of change from the Iron Age tradition as found in meat. ${ }^{64}$ However, there is some evidence that fish played a more important role in the diet; fish assemblages are both more numerous and more varied, reflecting local marine, estuarine, and freshwater fisheries. Evidence for offshore fishing is rare, but cod may have been more commonly eaten in the Roman period in London than elsewhere. Favoured marine fish were eaten at inland Roman sites, while some native settlements continued to rely on local freshwater species

The best evidence for an imported species is for Spanish mackerel. The finds were, with the

62

63 Ratcliffe and Straker 1996, 37.

64 King 1999. 
exception of Chester, from the South of England, the region where Romanisation might be expected to be most evident, being closest to Gaul. Finds of imported fish-sauce and evidence of possible domestic manufacture are exclusive to fish assemblages of Roman date. Red mullet and wrasse from Catterick (4) could also be imported. The Nile catfish spine from Dragonby may be an anomaly, brought in as a single bone; there are no other records of this species in Britain, but it was traded extensively in the Eastern Mediterranean. ${ }^{65}$

Eel ranks as the most common species overall by any measure, but there were regional patterns for other species. Salmon had a high profile, especially in the North and Midlands, and also from sites near the River Severn. It occurs in native settlements, Roman towns, and forts. There may have been a religious association with salmon at the Uley shrines, a continuation of Celtic totemic status. Although salmon would have been unknown in Italy, the military could have encountered it from the Atlantic coasts and rivers of Gaul and Spain, but it was particularly abundant in Britain, together with eel, as observed by Bede in the seventh century. ${ }^{66}$ Salmon may represent a native British influence on Roman fish consumption, becoming increasingly popular in this period.

Status is difficult to discern from fish bones. The Poundbury isotope data have been used to suggest that fish, or marine resources in general, were a status food ${ }^{67}$ Status can also be reflected in the size of a fish, but sturgeon - a large fish of impressive appearance and highly-regarded in Rome - was only found at two sites, both in Southwark. Fresh marine fish delivered inland, or kept live in ponds outside their normal environment, would be a mark of status as defined by van Neer and Ervynck, ${ }^{68}$ but this cannot be proven. Secondary evidence, such as the vestiges of fish-ponds, hints at some possibilities.

The Roman introduction into Britain of a distinct kitchen space was part of a radical culinary change. ${ }^{69}$ Roman cooking utensils and methods would have become desirable and affected the preparation and structure of meals. Perhaps fish became more fashionable? Native Britons in close contact with Romans would have been the first to emulate these changes which filtered through society. Trade in towns spread new goods, such as salsamenta, garum, liquamen, muria and allec via shops and markets. Some native farms evolved to imitate Roman villas in structure and culture, while the more remote native settlements remained largely unchanged. Most of the fish identified from excavation would have already been familiar to Romans coming to Britain; they feature in contemporary cookery accounts. ${ }^{70}$ The ingredients for fish-sauces included fruits and plants that either had to be imported, or the recipe adapted to use indigenous plants.

Unfortunately these changes must remain speculative since the linkage of fish bones to the apparatus of new cooking methods and ingredients is only inferred, largely from contemporary finds and documentary sources. However, it seems likely that the Romanisation of Britain introduced new elevated attitudes to fish as part of a wider culinary change, preparing local fish in a more sophisticated way: early 'fusion cooking' taking place in a new, defined space, the kitchen.

65 van Neer et al. 2004.

66 Bede, Hist. Eccl. I.1.

67 Richards and Hodges 1998.

68 Van Neer and Ervynck 2004.

69 Alcock 2001, 99.

70 Flower and Rosenbaum 1980. 


\section{APPENDIX}

TABLE 1. SPECIES LIST (Habitat notes from Wheeler 1978)

Common Name
Elasmobranch
Tope
Roker
Rajidae
Sturgeon
Eel
Conger eel
Herring
Sprat
Shad
Clupeid
Salmonidae
Trout
Grayling
Smelt
Pike
c.f. Crucian carp
Tench
Bitterling
Bream
Silver bream
Bleak
Barbel
Gudhe
Sodgeot
Dadone
Cyprinidae
Chub
Chub/dace
Roach/chub
Roach

\section{Latin name}

Cartilaginous fish

Galeorhinus galeus

Raja clavata

Ray family indet.

Acipenser sturio

Anguilla anguilla

Conger conger

Clupea harengus

Sprattus sprattus

Alosa sp.

Herring family indet.

c.f. Salmo salar

Salmo trutta

Thymallus thymallus

Osmerus eperlanus

Esox lucius

Carassius carassius

Tinca tinca

Rhodeus sericus

Abramis brama

Blicca bjoerkna

Alburnus alburnus

Barbus barbus

Gobio gobio

Leuciscus leuciscus

Leuciscus cephalus

Leuciscus leuciscus/cephalus

Rutilus rutilus/Leuciscus cephalus

Rutilus rutilus

Rutilus rutilus/Scardinius erythrophthalmus

Noemacheilus barbatulus

Carp family indet.

Lophius piscatorius

Gadus morhua

Melanogrammus aeglefinus

Merlangius merlangus

Trisopterus minutus

Pollachius pollachius

Pollachius virens

Lota lota

Sm species of cod family

\section{Habitat}

marine

marine

marine

marine

shallow marine and

freshwater

migratory

marine

marine

marine

migratory

migratory

freshwater

freshwater

migratory

freshwater

freshwater

freshwater

freshwater

freshwater

freshwater

freshwater

freshwater

freshwater

freshwater

freshwater

freshwater

freshwater

freshwater

freshwater

freshwater

freshwater

marine

marine

marine

marine

marine

marine

marine

freshwater incl. sharks \& rays

shark, shore to $200 \mathrm{~m}$

ray common $10-60 \mathrm{~m}$

all ray species

matures in rivers

rocky coasts

young in estuaries

young in estuaries

spawns in rivers

herring, sprat \& shad

spawns in rivers

rivers

rivers and lakes

spawns in rivers

lowland rivers \& lakes

native SE England only

slow rivers, lakes, ponds

?introduced

slow, lowland river/lakes

slow, lowland river/lakes

lowland and upstream

lowland rivers, weirpools variety of rivers \& lakes low/mid river reaches $\mathrm{mid}$ /upstream rivers

lowland rivers \& lakes

running water, various inc Cr. Carp to St. loach bottom living to $18 \mathrm{~m}$ depth seasonally to $600 \mathrm{~m}$ seasonally shallow/deep shallow, 30-100m coastal 24-300m depth inshore to $200 \mathrm{~m}$ inshore juv, adult to $250 \mathrm{~m}$ lowland slow river/lakes e.g. whiting, poor cod 
TABLE 1 (Cont.). SPECIES LIST (Habitat notes from Wheeler 1978)

Common Name

Large gadid

Gadidae

Ling

Hake

Garfish

Sandsmelt

John dory

Stickleback

Gurnard

Bullhead

Bass

Perch

Ruffe

Scad

Black sea bream

Red sea bream

Gilthead

Sparidae

Meagre

Red mullet

Thick lipped grey mullet

Thin lipped grey mullet

Mugilidae

Cuckoo wrasse

Ballan wrasse

Labridae

Catfish

Sandeel

Mackerel

Spanish mackerel

Scombridae

Turbot

Plaice

Flounder

Dab

Lemon sole

Halibut

Pleuronectidae

Flatfish indet.

Nile catfish

\section{Latin name}

Lg species of cod family

Cod family

Molva molva

Merluccius merluccius

Belone belone

Atherina presbyter

Zeus faber

Gasterosteus aculeatus

Triglidae

Cottus gobio

Dicentrarchus labrax

Perca fluviatilis

Gymnocephalus cernuus

Trachurus trachurus

Spondyliosoma cantharus

Pagellus bogaraveo

Sparus aurata

Sea bream family

Argyrosomus regius

Mullus surmuletus

Chelon labrosus

Liza ramada

Grey mullet family

Labrus mixtus

Labrus bergylta

Wrasse family

Anarhichas lupus

Ammodytes tobianus

Scomber scombrus

Scomber japonicus

Mackerel family

Scophthalmus maximus

Pleuronectes platessa

Platichthys flesus

Limanda limanda

Microstomus kitt

Hippoglossus hippoglossus

Right eyed flatfishes

Any flatfish

Synodontis sp.
Habitat

cod, saithe pollack

any member

marine

marine

marine

shallow marine and

freshwater

marine

freshwater to fully

marine

marine

freshwater

marine

freshwater

freshwater

marine

marine

marine

marine

marine

marine

marine

marine

marine

marine

marine

marine

marine

marine

marine

marine

marine

marine

marine

marine

marine

marine

marine

marine

marine

marine

freshwater deep water 3-400m

inshore summer, \& $550 \mathrm{~m}$

surface in and off shore

inshore/estuarine

inshore 10-50m depth

shallow water

stony streams \& lakes

inshore \& estuaries

slow rivers, lakes, ponds

slow rivers, lakes, ponds

surface, off \& onshore

rocky outcrops

inshore \& $100 \& 200 \mathrm{~m}$

sand/mud bottoms - 30m

black/red, gilthead etc.

rare, inshore, estuaries

inshore $3-90 \mathrm{~m}$

coastal and estuaries

coastal into freshwater

thick \& thin lipped

inshore summer \& $180 \mathrm{~m}$

rocky shores $2-20 \mathrm{~m}$

cuckoo, ballan.

60-300 m

tide level to $30 \mathrm{~m}$

surface on $\&$ offshore

surface inshore to $300 \mathrm{~m}$

atlantic or spanish

shallow inshore to $80 \mathrm{~m}$

sandy bottoms, $0-200 \mathrm{~m}$

$0-50 \mathrm{~m}$ also freshwater sandy bootoms $20-40 \mathrm{~m}$

40-200m

deepwater $100-1500 \mathrm{~m}$

incl. plaice to halibut

indet. to family or species

Traded 


\section{TABLE 2. GAZETEER OF THE SITES WITH FISH BONE DIVIDED BY REGION}

\section{North}

$\begin{array}{ll} & \text { Site } \\ 1 & \text { Birdoswald, Cumbria } \\ 2 & \text { Carlisle, Castle Street } \\ 3 & \text { Carlisle, The Lanes } \\ 4 & \text { Catterick Bridge, } \\ & \text { Thornborough Farm } \\ 5 & \text { Inveresk, Edinburgh } \\ 6 & \text { Lancaster } \\ 7 & \text { Ribchester, The Lanes } \\ 8 & \text { York, Bedern } \\ 9 & \text { York, Church Street } \\ 10 & \text { York, Fishergate } \\ 11 & \text { York, Skeldergate } \\ 12 & \text { York, Tanner Row }\end{array}$

$\begin{array}{ll}\text { Site Type } & \text { Date } \\ \text { fort } & \text { C3rd } \\ \text { military } & \text { C1st, 2nd } \\ \text { urban } & \text { C1st, 2nd } \\ \text { military/civilian } & \text { C2nd, 3rd }\end{array}$
military/civilian
military
well
military

\section{Ref}

Smith 1993

Locker 1985

Nicholson 1993 b

Stallibrass 2002

Ceron-Carrasco 2002

Jones \& Shotter 1998

Nicholson 1993a

O’Connor 1988

Enghoff 2000

Enghoff 2000

Enghoff 2000

O’Connor 1988

\section{Date Ref}

garrison town

C1st, 2nd, 3rd

Jacques et al. 2004

13 Chester, 25 Bridge Street.

garrison town

settlement

C1st, 4th

Jones 2001

Jones 1996

town

C2nd, 3rd

Locker 1993

Nicholson 1992

AD 50-200, AD 200-400

town

town

settlement

C3rd, 4th

Nicholson 1999

Irving 1996

Locker 1998a

settlement $\quad \mathrm{C} 1 \mathrm{st}$

Nicholson 1995

town

C1st, 2nd, 3rd

Nicholson \& Scott

2004

baths/basilica of town $\quad$ C4th

Wroxeter, Shropshire

Locker 1997a

\section{South/South-East}

\section{Site}

24 Barton Court Farm, Abingdon, Oxon.

25 Beddington, Surrey

26 Bignor, West Sussex

27 Bishopstone, Sussex

28 Canterbury, Marlowe Car Park

29 Canvey Island, Site 1

30 Castle Copse, Wilts.

31 Chichester, Chapel Street

$\begin{array}{ll}\begin{array}{ll}\text { Site Type } \\ \text { settlement } \\ \text { villa - well } \\ \text { villa }\end{array} & \text { Date } \\ \text { settlement } & \mathrm{C} 3 \mathrm{rd} / 4 \text { th } \\ \text { town } & \mathrm{C} 2 \mathrm{nd} \\ \text { settlement } & \mathrm{C} 1 \mathrm{st}, \text { 2nd, 4th } \\ \text { villa } & \\ \text { town (garden) } & \mathrm{C} 3 \mathrm{rd}\end{array}$

\section{Ref}

Wheeler 1984

Locker unpub

Parfitt 1995

Jones 1997

Locker 1986a

Jones 1986

Jones 1997

Locker 1981 
TABLE 2 (Cont.). GAZETEER OF THE SITES WITH FISH BONE DIVIDED BY REGION

\section{South/South-East (cont.)}

\begin{tabular}{|c|c|c|c|c|}
\hline & Site & Site Type & Date & Ref \\
\hline 32 & Colchester, Culver Street & town & $\mathrm{C} 1 \mathrm{st}, 2 \mathrm{nd}, 3 \mathrm{rd}$ & Locker $1992 \mathrm{a}$ \\
\hline 33 & Colchester, Former Post Office & town & C1st, 2nd & Locker 2002 \\
\hline 34 & Colchester, Gilberd School & town & C1st, 2nd & Locker $1986 b$ \\
\hline 35 & Elm Farm, Heybridge, Essex & settlement & $\mathrm{C} 1 \mathrm{st}$, 3rd, 4th & Locker 1998b \\
\hline 36 & Fishbourne Palace, nr Chichester, Sussex & villa & Cist & Ingrem 2004 \\
\hline 37 & Gorhambury, nr St Albans, Herts. & villa & C1st, 2nd, 3rd & Locker 1990 \\
\hline 38 & Great Holts Farm, Boreham, Essex & villa & C4th & Murphy et al. 2000 \\
\hline 39 & Hayling Island, Sussex & temple & C4th & Locker unpub \\
\hline 40 & North Shoebury, Essex & settlement & Roman & Jones 1983 \\
\hline 41 & Meppershall, Beds. & settlement & $\mathrm{C} 2 \mathrm{nd}$ & Locker 2004 \\
\hline 42 & Silchester, nr Basingstoke, Hants. & town & $\mathrm{C} 3 \mathrm{rd}, 4$ th & $\begin{array}{l}\text { Hamilton Dyer } 1997, \\
2000 \text {, Ingrem } 2006\end{array}$ \\
\hline 43 & Skeleton Green, Stevenage, Herts. & oppidum & LIA/Roman & Wheeler 1981 \\
\hline
\end{tabular}

\section{LONDON}

City kindly supplied by Kevin Rielly of MoLAS from the Oracle listings (Liddle \& Pipe in prep.)

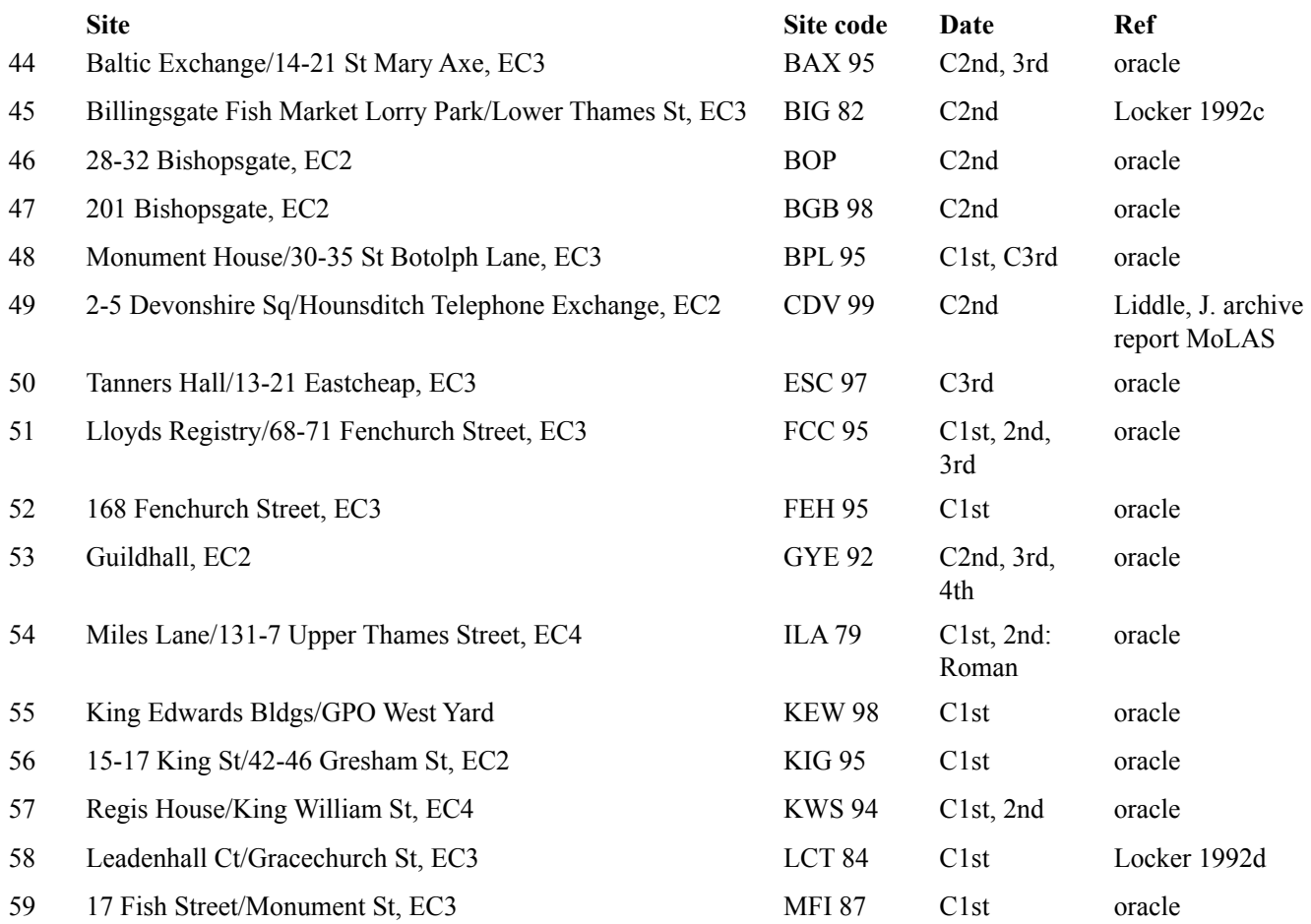


TABLE 2 (Cont.). GAZETEER OF THE SITES WITH FISH BONE DIVIDED BY REGION

\section{LONDON}

City (cont.)

$\begin{array}{lllll} & \text { Site } & \text { Site code } & \text { Date } & \text { Ref } \\ 60 & \text { Northgate House, Moorgate, EC2 } & \text { MRG 95 } & \text { C2nd, 3rd } & \text { oracle } \\ 61 & \text { 6-9 Newgate St. EC1 } & \text { NEG 98 } & \text { C1st, 2nd } & \text { oracle } \\ 62 & \text { 29 Gresham St, EC2 } & \text { NHG 98 } & \text { C1st, 2nd } & \text { oracle } \\ 63 & \text { No 1 Poultry, EC2 } & \text { ONE 94 } & \text { C1st, 2nd, } & \text { oracle } \\ 64 & \text { Pudding Lane, EC3 } & & \text { 3rd, 4th } & \text { oracle } \\ 65 & \text { Peninsular House/ Lower Thames St, EC3 } & \text { PDN 81 } & \text { C3rd } & \text { Bateman \& } \\ 66 & \text { Rangoon Street, EC3 } & \text { PEN 79 } & \text { C3rd } & \text { Locker 1982 } \\ 67 & \text { St Magnus } & \text { RAG 82 } & \text { C2nd } & \text { Locker 1986c } \\ 68 & \text { Billingsgate Bldgs/L Thames St, EC3 } & \text { SM 82 } & & \text { oracle } \\ 69 & \text { Fleet Valley, EC4 } & \text { TR 74 } & \text { C1st, 2nd } & \text { Wheeler } 1974\end{array}$
(unless otherwise credited the fish listed for London were identified by A. Pipe, C. Ainsley or J. Liddle).

East London cemeteries (all identified by A. Locker, archive reports for MoLAS) (Barber \& Bowsher 2000)

$\begin{array}{lll} & \text { Site } & \text { Site code } \\ 70 & \text { East Tenter St/Scarborough St, E1 } & \text { ETN 88 } \\ 71 & \text { 13 Haydon St, EC3 } & \text { HAY 86 } \\ 72 & \text { Hooper St, E1 } & \text { HOO 88 } \\ 73 & \text { 49-59 Mansell St/2-8 Alie St, E1 } & \text { MSL 87 } \\ 74 & \text { 31-43 Mansell St/1-15 Alie St, E1 } & \text { MST 87 } \\ 75 & \text { 53-66 Prescot St, E1 } & \text { PRE 89 } \\ 76 & \text { 9 St Claire St, EC3 } & \text { SCS 83 } \\ 77 & \text { 28-29 West Tenter St/59 Mansell St, E1 } & \text { WTE 90 }\end{array}$

\section{Southwark and sites in East London}

\begin{tabular}{lllll}
\multicolumn{2}{c}{ Site } & Site code & Date & \multicolumn{1}{c}{ Ref } \\
78 & Arcadia Buildings, Sylvester St & AB 78 & C1st, 4th & oracle \\
79 & New Wolfson Wing, Kings College, SE1 & BHB 00 & C3rd & Armitage 2002a \\
80 & 179 Borough High Street, SE1 & 179 BHS89 & C2nd & oracle \\
81 & 199 Borough High Street, SE1 & 199 BHS & C2nd & Jones 1988b \\
82 & Calverts Buildings, 15-23 Southwark St, SE1 & & C1st, 2nd & Locker 1991 \\
83 & Fennings Wharf, SE1 & FW 84 & C4th & Locker 1992d \\
84 & Babe Ruth Bathhouse, 172-6 The Highway, E1 & HGA 02 & C3rd, 4th & Armitage 2005a \\
85 & Hibernia Wharf, SE1 & HIB 79 & C3rd & oracle
\end{tabular}


TABLE 2 (Cont.). GAZETEER OF THE SITES WITH FISH BONE DIVIDED BY REGION

\section{LONDON}

Southwark and sites in East London (cont.)

$\begin{array}{ll} & \text { Site } \\ 86 & \text { Lefevre Road, Bow E3 } \\ 87 & \text { Shadwell Tower } \\ 88 & \text { Long Lane, SE1 } \\ 89 & \text { Southwark Cathedral, SE1 } \\ 90 & \text { Parnell Road, Bow, E3 } \\ 91 & \text { 4-26 St Thomas St, SE1 } \\ 92 & \text { 1-7 St Thomas St, SE1 } \\ 93 & \text { Swan St, SE1 } \\ 94 & \text { Tobacco Dock, 130-162 The Highway, EI } \\ 95 & \text { 10-18 Union St, SE1 } \\ 96 & \text { Winchester Palace. SE1 }\end{array}$

$\begin{array}{ll}\text { Site code } & \text { Date } \\ \text { L R } & \text { C2nd, 3rd, 4th } \\ \text { LD 76 } & \text { C4th } \\ \text { LGK 99 } & \text { C2nd } \\ \text { MTA 99 } & \text { C1st } \\ \text { PRB 95 } & \text { C2nd, 3rd, 4th } \\ \text { 4STS82 } & \text { C4th } \\ \text { 1-7 ST T } & \text { C2nd } \\ \text { SWN 98 } & \text { C2nd } \\ \text { TOC 02 } & \text { C3rd, 4th } \\ \text { USB 98 } & \text { C2nd, 3rd } \\ \text { WP 83 } & \text { C1st }\end{array}$

Ref

Locker $1998 \mathrm{c}$

oracle

Armitage 2000a

Armitage 2000b

Locker 1998d

oracle

Jones 1978

Armitage 2002b

Armitage 2005b

oracle

Yule 1989, 2005.

Rielly \& Locker

MoLAS unpub

\section{South \& South-West}

\begin{tabular}{lllll}
\multicolumn{2}{c}{ Site } & Site Type & Date & Ref \\
97 & Dorchester, County Hall, Dorset & town & C1st, 3rd, 4th & Hamilton Dyer 1993a \\
98 & Dorchester, Greyhound Yard, Dorset & town & $\begin{array}{l}\text { C1st, 2nd, 3rd, } \\
\text { 4th }\end{array}$ & Hamilton Dyer 1993b \\
99 & Exeter, Devon & town & & Wilkinson 1979 \\
100 & Figheldean, Wilts. & settlement & Early RB & Hamilton Dyer 1999 \\
101 & Ilchester, Great Yard, Somerset & town & C2nd & Locker 1997b \\
102 & Maddington Farm, Shrewton, Wilts. & settlement & & Hamilton Dyer 1996 \\
103 & Newquay, Cornwall & settlement & & Ingrem 2000 \\
104 & Ower, Somerset & settlement & C1st, 2nd & Coy 1987 \\
105 & Rope Lake, Dorset & settlement & & Coy 1987 \\
106 & Scillies, Halangy Down & settlement & C3rd & Locker 1996 \\
107 & Scillies, May Hill St Martin & settlement & & Turk 1984 \\
108 & Uley, Gloucestershire & shrines & C1st, 2nd, 4th & Wheeler 1993 \\
109 & Wadden Hill, Dorset & fort & C1st & Webster 1964, 1979
\end{tabular}


TABLE 3. TOTAL NUMBER OF FISH FOR EACH REGION BY NISP TOTAL AND OCCURRENCE

\begin{tabular}{|c|c|c|c|c|c|c|c|c|c|c|}
\hline Region & North & $\begin{array}{l}\text { Mid- } \\
\text { lands }\end{array}$ & $\begin{array}{r}\text { South/ } \\
\text { SEast }\end{array}$ & $\begin{array}{l}\text { Lon/ } \\
\text { City }\end{array}$ & $\begin{array}{l}\text { Lon/ } \\
\text { ELC }\end{array}$ & $\begin{array}{c}\text { Lon/ } \\
\text { Sou }\end{array}$ & $\begin{array}{l}\text { South/ } \\
\text { SWest }\end{array}$ & nisp tl & & $\begin{array}{c}\text { occ } / 109 \\
\text { sites }\end{array}$ \\
\hline Elasmobranch & 1 & 0 & 1 & 4 & 0 & 0 & 1 & 7 & & 6 \\
\hline Tope & 0 & 1 & 0 & 0 & 0 & 0 & 0 & 1 & & 1 \\
\hline Roker & 0 & 0 & 0 & 2 & 0 & 2 & 0 & 4 & & 3 \\
\hline Rajidae & 0 & 0 & 1 & 0 & 0 & 0 & 0 & 1 & & 1 \\
\hline Sturgeon & 0 & 0 & 0 & 0 & 0 & 6 & 0 & 6 & & 2 \\
\hline Eel & $571+$ & 413 & 568 & 218 & 25 & $241+$ & $732+$ & 2768 & + & 72 \\
\hline Conger eel & 0 & 0 & 0 & 1 & 0 & 1 & 13 & 15 & & 5 \\
\hline Herring & 64 & 99 & $145+$ & $33+$ & 38 & $41+$ & 0 & 420 & + & 44 \\
\hline Sprat & 0 & 0 & + & $58+$ & 2 & 4 & 0 & 64 & + & 6 \\
\hline Shad & $6+$ & 0 & 8 & 5 & $12 *$ & 2 & 0 & 33 & * & 9 \\
\hline Clupeidae & 11 & $44^{*}$ & $8+$ & $162+$ & 6 & 5 & 0 & 236 & $+*$ & 23 \\
\hline Salmonidae & $252+$ & 151 & 26 & 57 & 3 & 1 & 56 & 546 & + & 31 \\
\hline Trout & 12 & 1 & 28 & 0 & 0 & 0 & 0 & 41 & & 4 \\
\hline Grayling & 14 & * & 0 & 0 & 0 & 0 & 0 & 14 & * & 2 \\
\hline Smelt & 142 & 19 & 1 & $368+$ & 14 & $22+$ & 0 & 566 & + & 21 \\
\hline Pike & 22 & $91^{*}$ & 10 & 0 & 1 & $3+$ & 0 & 127 & $+*$ & 17 \\
\hline c.f. Crucian carp & 0 & 0 & 0 & 0 & 0 & 1 & 0 & 1 & & 1 \\
\hline Tench & 0 & $4^{*}$ & 0 & 0 & 0 & 0 & 0 & 4 & * & 3 \\
\hline Bitterling & 0 & 1 & 0 & 0 & 0 & 0 & 0 & 1 & & 1 \\
\hline Bream & 0 & 1 & 0 & 0 & 0 & 0 & 0 & 1 & & 1 \\
\hline Silver Bream & 0 & 0 & 0 & 7 & 0 & 0 & 0 & 7 & & 1 \\
\hline Bleak & 1 & 0 & 0 & 0 & 0 & 0 & 0 & 1 & & 1 \\
\hline Barbel & 1 & 1 & 0 & 4 & 0 & 0 & 0 & 6 & & 4 \\
\hline Gudgeon & 0 & 3 & 0 & 11 & 0 & + & 0 & 14 & + & 4 \\
\hline Dace & 4 & 1 & 0 & 21 & 0 & $1+$ & 0 & 27 & + & 6 \\
\hline Chub & 2 & 4 & 4 & 17 & 0 & + & 0 & 27 & + & 7 \\
\hline Chub/dace & 0 & 1 & 3 & 0 & 0 & 0 & 0 & 4 & & 2 \\
\hline Roach/Chub & 0 & 11 & 0 & 0 & 0 & 0 & 0 & 11 & & 2 \\
\hline Roach & 2 & 4 & 3 & 36 & 0 & 2 & 0 & 47 & & 9 \\
\hline Roach/Rudd & 0 & 1 & 0 & 0 & 0 & 0 & 0 & 1 & & 1 \\
\hline Stone loach & 0 & 6 & 0 & 0 & 0 & 0 & 0 & 6 & & 1 \\
\hline Cyprinidae & 350 & 208 & $24 *$ & $532^{*}$ & 1 & $25+$ & 85 & 1225 & $+*$ & 33 \\
\hline Angler & 0 & 0 & 0 & 0 & 0 & 0 & 1 & 1 & & 1 \\
\hline Cod & 2 & 1 & 7 & 57 & 1 & 14 & 0 & 82 & & 21 \\
\hline Haddock & 3 & 0 & 5 & 3 & 0 & + & 0 & 11 & + & 6 \\
\hline Whiting & 1 & 0 & $20+$ & 7 & 4 & 1 & $8+$ & 41 & + & 20 \\
\hline Poor cod & 0 & 0 & 2 & 0 & 0 & 0 & 0 & 2 & & 2 \\
\hline Pollack & 0 & 0 & 0 & 0 & 0 & 0 & $1+$ & 1 & + & 2 \\
\hline Saithe & 0 & 0 & 1 & 0 & 0 & 0 & 0 & 1 & & 1 \\
\hline Burbot & 3 & 0 & 0 & 0 & 0 & 0 & 0 & 3 & & 1 \\
\hline Small gadid & 0 & 0 & 29 & 0 & 0 & 13 & 0 & 42 & & 5 \\
\hline Large Gadid & 0 & 0 & 8 & 12 & 0 & 0 & 0 & 20 & & 5 \\
\hline Gadidae & 5 & 1 & 0 & $36+$ & 1 & $15+$ & 6 & 64 & + & 21 \\
\hline Ling & 0 & 0 & 0 & 1 & 0 & 0 & + & 1 & + & 2 \\
\hline Hake & 3 & 0 & 1 & 0 & 0 & 0 & 5 & 9 & & \\
\hline
\end{tabular}


TABLE 3 (Cont.). TOTAL NUMBER OF FISH FOR EACH REGION BY NISP TOTAL AND OCCURRENCE

\begin{tabular}{|c|c|c|c|c|c|c|c|c|c|c|}
\hline Region & North & $\begin{array}{l}\text { Mid- } \\
\text { lands }\end{array}$ & $\begin{array}{c}\text { South/ } \\
\text { SEast }\end{array}$ & $\begin{array}{c}\text { Lon/ } \\
\text { City }\end{array}$ & $\begin{array}{l}\text { Lon/ } \\
\text { ELC }\end{array}$ & $\begin{array}{c}\text { Lon/ } \\
\text { Sou }\end{array}$ & $\begin{array}{l}\text { South/ } \\
\text { SWest }\end{array}$ & nisp & & $\begin{array}{c}\text { occ/109 } \\
\text { sites }\end{array}$ \\
\hline Garfish & 0 & 0 & 7 & 0 & 0 & 0 & 0 & 7 & & 1 \\
\hline Sandsmelt & 0 & 0 & 0 & + & 0 & 0 & 0 & + & & 1 \\
\hline John dory & 0 & 0 & 0 & 0 & 0 & 0 & + & + & & 1 \\
\hline Stickleback & 1 & 0 & $20+$ & + & 0 & 18 & 0 & 39 & + & 7 \\
\hline Gurnard & 1 & 4 & 1 & 0 & 0 & 1 & 2 & 9 & & 8 \\
\hline Bullhead & 0 & 1 & + & 0 & 0 & 0 & 0 & 1 & + & 2 \\
\hline Bass & 0 & 2 & 37 & $21+$ & 0 & 0 & $274+$ & 334 & + & 11 \\
\hline Perch & $75+$ & 138 & $1 *$ & 11 & 0 & 0 & $3 *$ & 228 & $+*$ & 17 \\
\hline Ruffe & 0 & 2 & 0 & 0 & 0 & 0 & 0 & 2 & & 2 \\
\hline Scad & 1 & 0 & 8 & 0 & 0 & 0 & 11 & 20 & & 6 \\
\hline Black sea bream & 0 & 0 & 0 & 2 & 0 & 3 & 1 & 6 & & 5 \\
\hline Red sea bream & 0 & 0 & 1 & + & 0 & 0 & 10 & 11 & + & 4 \\
\hline Gilthead & 0 & 0 & 1 & 0 & 0 & 0 & 3 & 4 & & 3 \\
\hline Sparidae & $6+$ & 0 & 13 & 1 & 0 & 0 & 57 & 77 & + & 10 \\
\hline Meagre & 0 & 0 & 1 & 0 & 0 & 0 & 0 & 1 & & 1 \\
\hline Red mullet & 2 & 0 & 0 & 0 & 0 & 0 & 0 & 2 & & 1 \\
\hline Thick $1 \mathrm{~g}$ mullet & 1 & 0 & 17 & 1 & 0 & 0 & 0 & 19 & & 4 \\
\hline Thin $1 \mathrm{~g}$ mullet & 0 & 3 & 2 & 0 & 0 & 1 & 0 & 6 & & 4 \\
\hline Mugildae & 3 & 34 & 9 & 11 & 0 & 1 & $58+$ & 116 & + & 13 \\
\hline Cuckoo wrasse & 0 & 0 & 0 & 0 & 0 & 0 & $1+$ & 1 & + & 2 \\
\hline Ballan wrasse & 1 & 0 & 0 & 0 & 0 & 0 & $17+$ & 18 & + & 5 \\
\hline Labridae & 4 & 0 & 1 & 1 & 0 & 0 & $129+$ & 135 & + & 11 \\
\hline Catfish & 2 & 0 & 0 & 0 & 0 & 0 & 0 & 2 & & 1 \\
\hline Sandeel & 1 & 40 & 0 & + & 0 & 0 & 0 & 41 & + & 3 \\
\hline Mackerel & 4 & 11 & 29 & 22 & 1 & $3+$ & 2 & 72 & + & 23 \\
\hline Spanish mackerel & 0 & 3 & 4 & 0 & 0 & + & 0 & 7 & + & 4 \\
\hline Scombridae & 0 & 0 & 3 & 0 & 0 & 0 & 0 & 3 & & 1 \\
\hline Turbot & 0 & 0 & 1 & 10 & 0 & 0 & 1 & 12 & & 3 \\
\hline Plaice & 3 & 4 & $58+$ & 3 & 0 & 0 & $3+$ & 71 & + & 15 \\
\hline Flounder & 6 & 3 & 11 & $10+$ & 1 & 0 & 8 & 39 & + & 11 \\
\hline Plaice/flounder & 63 & 82 & 159 & $399+$ & 11 & 23 & 22 & 759 & + & 43 \\
\hline Dab & 0 & 0 & 7 & 0 & 1 & 0 & 0 & 8 & & 2 \\
\hline Lemon sole & 1 & 0 & 0 & 0 & 0 & 0 & 0 & 1 & & 1 \\
\hline Halibut & 0 & 0 & 1 & 0 & 0 & 0 & 0 & 1 & & 1 \\
\hline Flatfish & $26+$ & 15 & $153+$ & 7 & 0 & 8 & 24 & 233 & + & 27 \\
\hline Nile catfish & 0 & 1 & 0 & 0 & 0 & 0 & 0 & 1 & & 1 \\
\hline Total & $1673+$ & $1410 *$ & $1448+*$ & $2151+*$ & $122 *$ & $458+$ & $1534+*$ & 8796 & $+*$ & \\
\hline occ/82 sp & 40 & 39 & 48 & 40 & 16 & 31 & 30 & & & \\
\hline
\end{tabular}


TABLE 4. THE NORTH; THE FISH FROM 12 SITES BY NISP TOTAL AND OCCURRENCE.

\begin{tabular}{|c|c|c|c|c|c|c|c|c|c|c|c|c|c|c|}
\hline Site \& Site no & $1 \mathrm{Bir}$ & $\begin{array}{r}2 \mathrm{Car} \\
\mathrm{C}\end{array}$ & $\begin{array}{r}3 \mathrm{Car} \\
\mathrm{L}\end{array}$ & 4 Cat & $5 \mathrm{Inv}$ & 6 Lan & 7 Rib & $\begin{array}{r}8 \text { Yor } \\
\text { B }\end{array}$ & $\begin{array}{r}9 \text { Yor } \\
\mathrm{C}\end{array}$ & $\begin{array}{r}10 \\
\text { YorF }\end{array}$ & $\begin{array}{r}11 \\
\text { YorS }\end{array}$ & $\begin{array}{r}12 \\
\text { YorT }\end{array}$ & Total & $\begin{array}{r}\text { occ } / 12 \\
\text { sites }\end{array}$ \\
\hline Elasmobranch & 0 & 0 & 0 & 0 & 0 & 0 & 0 & 0 & 0 & 1 & 0 & 0 & 1 & 1 \\
\hline Eel & 0 & 73 & 353 & 0 & 0 & 0 & 2 & 0 & 29 & 10 & + & 104 & $571+$ & 7 \\
\hline Herring & 0 & 0 & 0 & 1 & 2 & 0 & 0 & 0 & 0 & 50 & 0 & 11 & 64 & 4 \\
\hline Shad & 0 & 0 & 1 & 0 & 0 & 0 & 0 & 0 & 0 & 0 & + & 5 & $6+$ & 3 \\
\hline Clupeid & 0 & 0 & 0 & 0 & 0 & 0 & 0 & 0 & 0 & 0 & 0 & 11 & 11 & 1 \\
\hline Salmonid & + & 141 & 83 & 1 & 6 & 1 & 3 & 0 & 0 & 0 & 0 & 17 & $252+$ & 8 \\
\hline Trout & 0 & 0 & 1 & 0 & 0 & 0 & 0 & 0 & 0 & 0 & 0 & 11 & 12 & 2 \\
\hline Grayling & 0 & 0 & 0 & 0 & 0 & 0 & 0 & 0 & 0 & 0 & 0 & 14 & 14 & 1 \\
\hline Smelt & 0 & 0 & 0 & 0 & 0 & 0 & 4 & 0 & 82 & 0 & 0 & 56 & 142 & 3 \\
\hline Pike & 0 & 0 & 11 & 0 & 0 & 0 & 0 & 0 & 0 & 1 & 0 & 10 & 22 & 3 \\
\hline Bleak & 0 & 0 & 0 & 0 & 0 & 0 & 0 & 0 & 1 & 0 & 0 & 0 & 1 & 1 \\
\hline Barbel & 0 & 0 & 0 & 0 & 0 & 0 & 0 & 0 & 0 & 0 & 0 & 1 & 1 & 1 \\
\hline Dace & 0 & 0 & 0 & 0 & 0 & 0 & 0 & 0 & 0 & 0 & 0 & 4 & 4 & 1 \\
\hline Chub & 0 & 0 & 0 & 0 & 0 & 0 & 0 & 0 & 0 & 0 & 0 & 2 & 2 & 1 \\
\hline Roach & 0 & 0 & 0 & 0 & 0 & 0 & 0 & 0 & 2 & 0 & 0 & 0 & 2 & 1 \\
\hline Cyprinidae & 0 & 0 & 0 & 0 & 0 & 0 & 1 & 0 & 3 & 0 & 0 & 346 & 350 & 3 \\
\hline Cod & 0 & 0 & 1 & 0 & 1 & 0 & 0 & 0 & 0 & 0 & 0 & 0 & 2 & 2 \\
\hline Haddock & 0 & 0 & 2 & 0 & 0 & 0 & 0 & 0 & 0 & 1 & 0 & 0 & 3 & 2 \\
\hline Whiting & 0 & 0 & 0 & 0 & 0 & 0 & 0 & 0 & 0 & 1 & 0 & 0 & 1 & 1 \\
\hline Burbot & 0 & 0 & 0 & 0 & 0 & 0 & 0 & 0 & 0 & 0 & 0 & 3 & 3 & 1 \\
\hline Gadidae & 0 & 0 & 2 & 0 & 3 & 0 & 0 & 0 & 0 & 0 & 0 & 0 & 5 & 2 \\
\hline Hake & 0 & 3 & 0 & 0 & 0 & 0 & 0 & 0 & 0 & 0 & 0 & 0 & 3 & 1 \\
\hline Stickleback & 0 & 0 & 0 & 0 & 0 & 0 & 0 & 0 & 1 & 0 & 0 & 0 & 1 & 1 \\
\hline Gurnard & 0 & 0 & 0 & 0 & 1 & 0 & 0 & 0 & 0 & 0 & 0 & 0 & 1 & 1 \\
\hline Perch & 0 & 0 & 0 & 0 & 0 & 0 & 0 & 0 & 5 & 1 & + & 69 & $75+$ & 4 \\
\hline Scad & 0 & 0 & 0 & 0 & 0 & 0 & 0 & 0 & 0 & 0 & 0 & 1 & 1 & 1 \\
\hline Sparidae & 0 & 0 & 0 & 0 & 0 & 0 & 0 & + & 0 & 0 & 0 & 6 & $6+$ & 2 \\
\hline Red Mullet & 0 & 0 & 0 & 2 & 0 & 0 & 0 & 0 & 0 & 0 & 0 & 0 & 2 & 1 \\
\hline $\begin{array}{l}\text { Thick } 1 \mathrm{~g} \\
\text { mullet }\end{array}$ & 0 & 0 & 0 & 0 & 0 & 0 & 1 & 0 & 0 & 0 & 0 & 0 & 1 & 1 \\
\hline Mugildae & 0 & 2 & 0 & 1 & 0 & 0 & 0 & 0 & 0 & 0 & 0 & 0 & 3 & 2 \\
\hline Ballan wrasse & 0 & 0 & 0 & 0 & 1 & 0 & 0 & 0 & 0 & 0 & 0 & 0 & 1 & 1 \\
\hline Labridae & 0 & 2 & 0 & 1 & 1 & 0 & 0 & 0 & 0 & 0 & 0 & 0 & 4 & 3 \\
\hline Catfish & 0 & 0 & 0 & 2 & 0 & 0 & 0 & 0 & 0 & 0 & 0 & 0 & 2 & 1 \\
\hline Sandeel & 0 & 0 & 0 & 0 & 1 & 0 & 0 & 0 & 0 & 0 & 0 & 0 & 1 & 1 \\
\hline Mackerel & 0 & 1 & 1 & 0 & 2 & 0 & 0 & 0 & 0 & 0 & 0 & 0 & 4 & 3 \\
\hline Plaice & 0 & 3 & 0 & 0 & 0 & 0 & 0 & 0 & 0 & 0 & 0 & 0 & 3 & 1 \\
\hline Flounder & 0 & 5 & 0 & 0 & 0 & 0 & 0 & 0 & 0 & 0 & 0 & 1 & 6 & 2 \\
\hline Pleuronectid/P/F & 0 & 13 & 16 & 0 & 0 & 0 & 1 & 0 & 0 & 0 & 0 & 33 & 63 & 4 \\
\hline Lemon sole & 0 & 0 & 0 & 0 & 1 & 0 & 0 & 0 & 0 & 0 & 0 & 0 & 1 & 1 \\
\hline Flatfish & 0 & 20 & 4 & 0 & 2 & 0 & 0 & 0 & 0 & 0 & + & 0 & $26+$ & 4 \\
\hline Total & + & 263 & 475 & 8 & 21 & 1 & 12 & + & 123 & 65 & + & 705 & $1673+$ & \\
\hline Occ/41 sp & 1 & 10 & 11 & 6 & 11 & 1 & 6 & 1 & 7 & 7 & 4 & 19 & & \\
\hline
\end{tabular}


TABLE 5. THE MIDLANDS; THE FISH FROM 11 SITES BY NISP TOTAL AND OCCURRENCE.

\begin{tabular}{|c|c|c|c|c|c|c|c|c|c|c|c|c|c|}
\hline & $\begin{array}{r}13 \\
\text { Che }\end{array}$ & $\begin{array}{r}14 \\
\text { Che }\end{array}$ & $\begin{array}{r}15 \\
\text { Dra }\end{array}$ & $\begin{array}{r}16 \\
\text { God }\end{array}$ & $\begin{array}{r}17 \\
\text { Lei }\end{array}$ & $\begin{array}{r}18 \\
\text { Lei }\end{array}$ & $\begin{array}{r}19 \\
\text { Lin }\end{array}$ & $\begin{array}{r}20 \\
\text { Rec }\end{array}$ & $\begin{array}{r}21 \\
\text { The }\end{array}$ & $\begin{array}{r}22 \\
\text { Wor }\end{array}$ & $\begin{array}{r}23 \\
\text { Wro }\end{array}$ & total & $\begin{array}{c}\text { occ/11 } \\
\text { sites }\end{array}$ \\
\hline Tope & 0 & 0 & 0 & 0 & 0 & 0 & 0 & 0 & 0 & 1 & 0 & 1 & 1 \\
\hline Eel & 10 & 23 & 1 & 35 & 19 & 224 & 64 & 34 & 2 & 1 & 0 & 413 & 10 \\
\hline Herring & 3 & 0 & 0 & 1 & 14 & 76 & 0 & 0 & 3 & 2 & 0 & 99 & 6 \\
\hline Clupeid & 0 & 6 & 0 & 0 & $1^{*}$ & 37 & 0 & 0 & 0 & 0 & 0 & $44 *$ & 3 \\
\hline Salmonid & 2 & 42 & 1 & 0 & 1 & 6 & 4 & 0 & 0 & 1 & 94 & 151 & 8 \\
\hline Trout & 0 & 0 & 0 & 0 & 0 & 1 & 0 & 0 & 0 & 0 & 0 & 1 & 1 \\
\hline Grayling & 0 & 0 & 0 & 0 & * & 0 & 0 & 0 & 0 & 0 & 0 & * & 1 \\
\hline Smelt & 0 & 17 & 0 & 0 & 1 & 1 & 0 & 0 & 0 & 0 & 0 & 19 & 3 \\
\hline Pike & 0 & 0 & 1 & 7 & * & 6 & 8 & 5 & 0 & 0 & 64 & $91 *$ & 7 \\
\hline Tench & 0 & 0 & 0 & 0 & $1 *$ & 2 & 1 & 0 & 0 & 0 & 0 & $4 *$ & 3 \\
\hline Bream & 0 & 0 & 0 & 0 & 0 & 0 & 1 & 0 & 0 & 0 & 0 & 1 & 1 \\
\hline Barbel & 0 & 0 & 0 & 0 & 0 & 0 & 1 & 0 & 0 & 0 & 0 & 1 & 1 \\
\hline Gudgeon & 0 & 0 & 0 & 0 & 1 & 2 & 0 & 0 & 0 & 0 & 0 & 3 & 2 \\
\hline Bitterling & 0 & 0 & 0 & 0 & 0 & 0 & 1 & 0 & 0 & 0 & 0 & 1 & 1 \\
\hline Dace & 0 & 0 & 0 & 0 & 0 & 0 & 0 & 1 & 0 & 0 & 0 & 1 & 1 \\
\hline Roach/chub & 0 & 0 & 0 & 0 & 0 & 0 & 2 & 0 & 0 & 0 & 9 & 11 & 2 \\
\hline Roach/rudd & 0 & 0 & 0 & 0 & 0 & 1 & 0 & 0 & 0 & 0 & 0 & 1 & 1 \\
\hline Chub & 0 & 0 & 0 & 0 & 0 & 0 & 0 & 0 & 0 & 0 & 4 & 4 & 1 \\
\hline Chub/dace & 0 & 0 & 0 & 0 & 0 & 1 & 0 & 0 & 0 & 0 & 0 & 1 & 1 \\
\hline Roach & 0 & 0 & 0 & 1 & 0 & 0 & 2 & 0 & 0 & 0 & 1 & 4 & 3 \\
\hline Stone loach & 0 & 0 & 0 & 0 & 0 & 0 & 6 & 0 & 0 & 0 & 0 & 6 & 1 \\
\hline Cyprinidae & 0 & 0 & 0 & 4 & $4 *$ & 47 & 142 & 6 & 0 & 1 & 4 & $208 *$ & 7 \\
\hline Cod & 0 & 0 & 0 & 0 & 0 & 0 & 0 & 0 & 0 & 1 & 0 & 1 & 1 \\
\hline Gadid & 0 & 0 & 0 & 0 & 0 & 1 & 0 & 0 & 0 & 0 & 0 & 1 & 1 \\
\hline Perch & 0 & 0 & 0 & 2 & 1 & 23 & 40 & 2 & 0 & 0 & 70 & 138 & 6 \\
\hline Ruffe & 0 & 0 & 0 & 0 & 0 & 0 & 1 & 0 & 0 & 0 & 1 & 2 & 2 \\
\hline Gurnard & 0 & 0 & 0 & 0 & 1 & 2 & 1 & 0 & 0 & 0 & 0 & 4 & 3 \\
\hline Bullhead & 0 & 0 & 0 & 0 & 0 & 0 & 1 & 0 & 0 & 0 & 0 & 1 & 1 \\
\hline Bass & 1 & 0 & 0 & 0 & 0 & 0 & 0 & 0 & 0 & 0 & 1 & 2 & 2 \\
\hline Thin $1 \mathrm{~g}$ mullet & 0 & 0 & 0 & 0 & 0 & 0 & 0 & 0 & 0 & 0 & 3 & 3 & 1 \\
\hline Mugilidae & 34 & 0 & 0 & 0 & 0 & 0 & 0 & 0 & 0 & 0 & 0 & 34 & 1 \\
\hline Sandeel & 0 & 0 & 0 & 0 & 0 & 0 & 40 & 0 & 0 & 0 & 0 & 40 & 1 \\
\hline Mackerel & 0 & 0 & 0 & 0 & 0 & 9 & 0 & 0 & 0 & 0 & 2 & 11 & 2 \\
\hline Span mackerel & 3 & 0 & 0 & 0 & 0 & 0 & 0 & 0 & 0 & 0 & 0 & 3 & 1 \\
\hline Plaice & 0 & 0 & 0 & 0 & 0 & 0 & 0 & 1 & 0 & 0 & 3 & 4 & 2 \\
\hline Flounder & 1 & 0 & 0 & 0 & 0 & 1 & 0 & 1 & 0 & 0 & 0 & 3 & 3 \\
\hline PleuronectidP/F & 15 & 28 & 0 & 4 & 0 & 20 & 13 & 2 & 0 & 0 & 0 & 82 & 6 \\
\hline Flatfish & 0 & 0 & 0 & 2 & 2 & 10 & 0 & 1 & 0 & 0 & 0 & 15 & 4 \\
\hline Nile catfish & 0 & 0 & 1 & 0 & 0 & 0 & 0 & 0 & 0 & 0 & 0 & 1 & 1 \\
\hline Total & 69 & 116 & 4 & 56 & 46 & 470 & 328 & 53 & 5 & 7 & 256 & $1410 *$ & \\
\hline Occ/39 sp & 8 & 5 & 4 & 8 & 13 & 19 & 17 & 9 & 2 & 6 & 12 & & \\
\hline
\end{tabular}




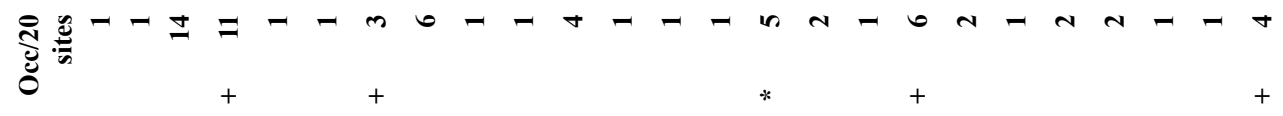

$$
\begin{aligned}
& \text { ప⿱艹⿹勹巳 } \\
& \text { F } \frac{1}{\omega} 00000000000+m 00000000000
\end{aligned}
$$

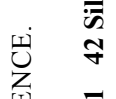

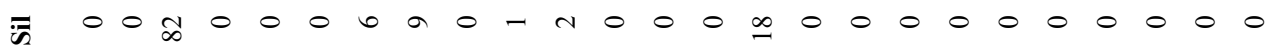

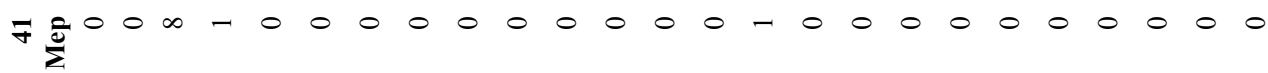

$$
\begin{aligned}
& \text { F } \\
& \text { ले } \\
& \text { 忽 } 0 \text { - } \\
& \text { n் j00 } \\
& \text { nీ } \\
& \text { m } \\
& \text { सु }
\end{aligned}
$$

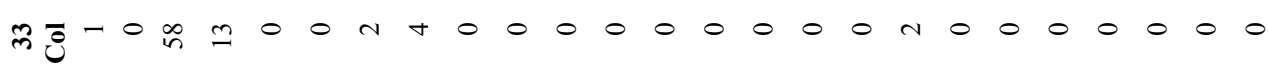

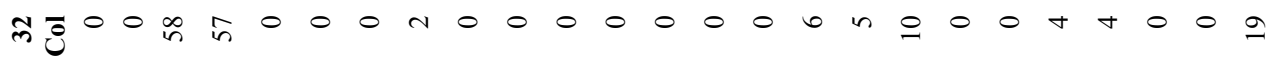

$$
\begin{aligned}
& \bar{m} \text { 苅 } 000+00000000000000000000
\end{aligned}
$$

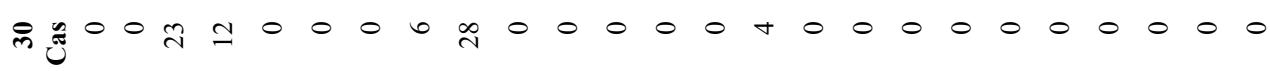

$$
\begin{aligned}
& \text { ลิU一 } 00+00+0000000000+000000+ \\
& \text { 㫕 } \\
& \text { 会 } 000000000000000000000000
\end{aligned}
$$

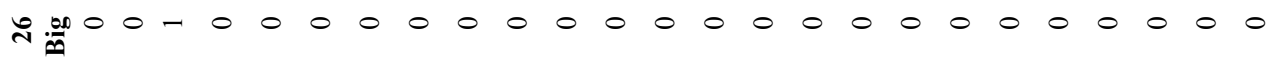

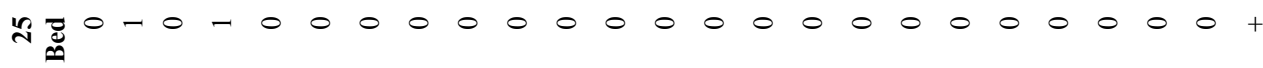

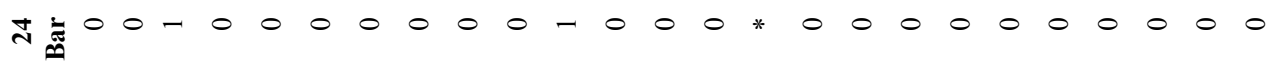

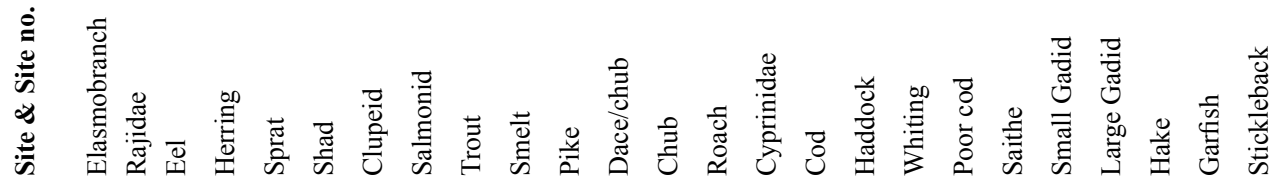




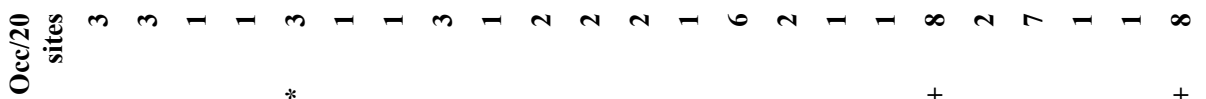

हैं

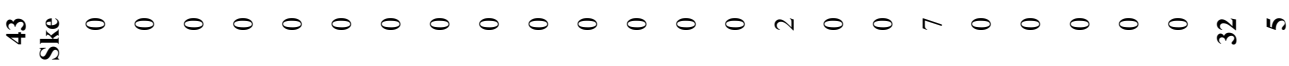

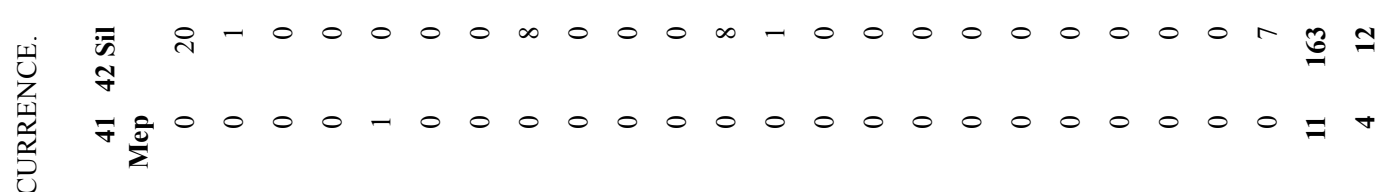

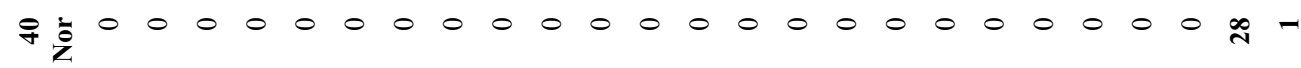
ले

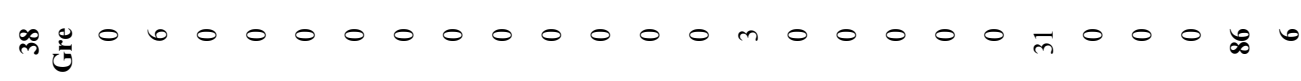

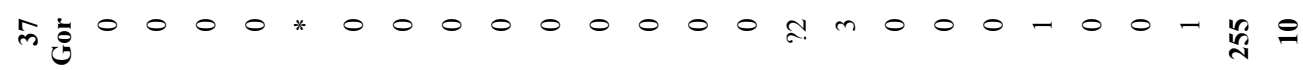

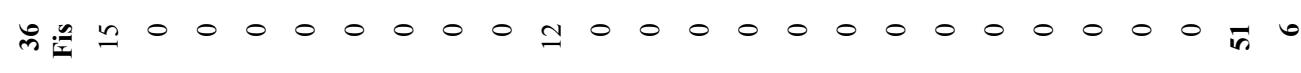
m

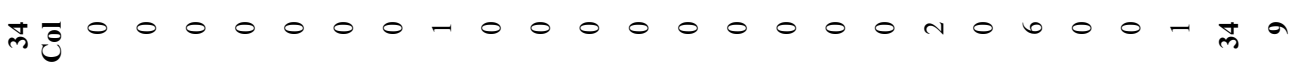
mं

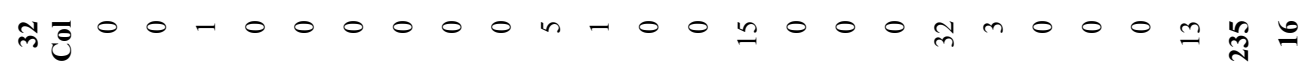
m. ల్

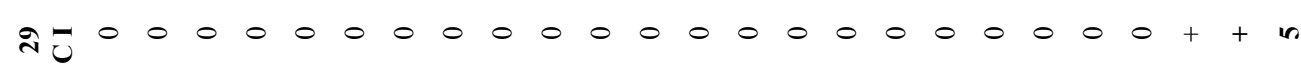
崩

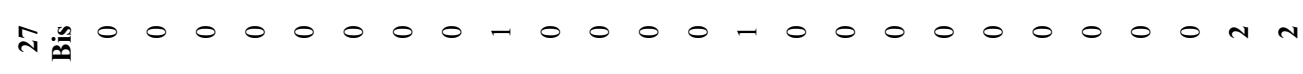

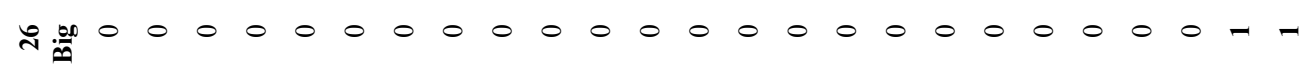

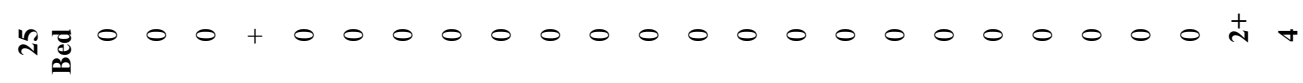
㫕

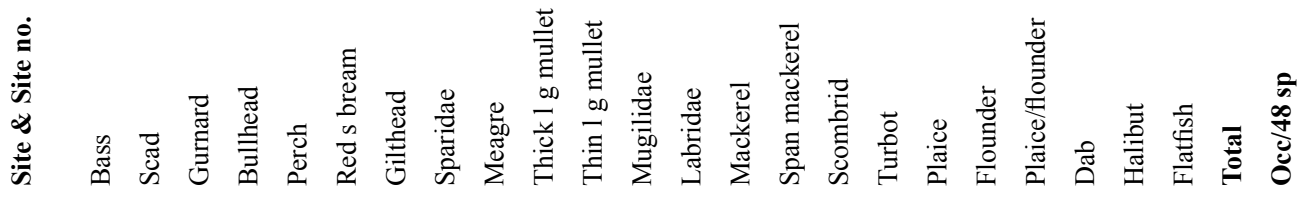


For TABLE 7. LONDON; THE FISH FROM 26 SITES BY NISP TOTAL AND OCCURRENCE. See overleaf pp. 172-3

TABLE 8. EAST LONDON CEMETERIES; THE FISH FROM 8 SITES BY NISP TOTAL AND OCCURRENCE.

$\begin{array}{lrrrrrrrrrr} & \boldsymbol{7 0} & \mathbf{7 1} & \mathbf{7 2} & \mathbf{7 3} & \mathbf{7 4} & \mathbf{7 5} & \mathbf{7 6} & \mathbf{7 7} & \text { nisp } & \begin{array}{r}\boldsymbol{o c c} \boldsymbol{8} \\ \text { Eel }\end{array} \\ \text { Herring } & 2 & 16 & 2 & 3 & 0 & 1 & 1 & 0 & \mathbf{2 5} & \mathbf{6} \\ \text { Sprat } & 1 & 2 & 28 & 1 & 1 & 1 & 0 & 4 & \mathbf{3 8} & \mathbf{7} \\ \text { Herring/sprat } & 0 & 0 & 2 & 0 & 0 & 0 & 0 & 0 & \mathbf{2} & \mathbf{1} \\ \text { Shad } & 0 & 0 & 0 & 0 & 0 & 0 & 0 & 6 & \mathbf{6} & \mathbf{1} \\ \text { Salmonid } & 0 & 10^{*} & 1 & 0 & 0 & 0 & 0 & 1 & \mathbf{1 2} & \mathbf{3} \\ \text { Smelt } & 0 & 3 & 0 & 0 & 0 & 0 & 0 & 0 & \mathbf{3} & \mathbf{1} \\ \text { Pike } & 0 & 0 & 2 & 0 & 0 & 0 & 0 & 12 & \mathbf{1 4} & \mathbf{2} \\ \text { Cyprinidae } & 0 & 0 & 1 & 0 & 0 & 0 & 0 & 0 & \mathbf{1} & \mathbf{1} \\ \text { Cod } & 0 & 0 & 1 & 0 & 0 & 0 & 0 & 0 & \mathbf{1} & \mathbf{1} \\ \text { Whiting } & 0 & 0 & 1 & 0 & 0 & 0 & 0 & 0 & \mathbf{1} & \mathbf{1} \\ \text { Gadidae } & 1 & 0 & 1 & 1 & 0 & 0 & 0 & 1 & \mathbf{4} & \mathbf{4} \\ \text { Mackerel } & 0 & 0 & 1 & 0 & 0 & 0 & 0 & 0 & \mathbf{1} & \mathbf{1} \\ \text { Flounder } & 0 & 1 & 0 & 0 & 0 & 0 & 0 & 0 & \mathbf{1} & \mathbf{1} \\ \text { Plaice/flounder } & 0 & 0 & 1 & 0 & 0 & 0 & 0 & 0 & \mathbf{1} & \mathbf{1} \\ \text { Dab } & 0 & 2 & 5 & 0 & 0 & 2 & 0 & 2 & \mathbf{1 1} & \mathbf{4} \\ \text { total } & 0 & 0 & 0 & 0 & 0 & 0 & 0 & 1 & \mathbf{1} & \mathbf{1} \\ \text { Occ/16 sp } & \mathbf{4} & \mathbf{3 4} & \mathbf{4 6} & \mathbf{5} & \mathbf{1} & \mathbf{4} & \mathbf{1} & \mathbf{2 7} & \mathbf{1 2 2 *} & \end{array}$


TABLE 7. LONDON; THE FISH FROM 26 SITES BY NISP TOTAL AND OCCURRENCE.

\begin{tabular}{|c|c|c|c|c|c|c|c|c|c|c|c|c|c|}
\hline Site \& Site no & $\begin{array}{r}44 \\
\text { BAX }\end{array}$ & $\begin{array}{r}45 \\
\text { BIG }\end{array}$ & $\begin{array}{r}46 \\
\text { BOP }\end{array}$ & $\begin{array}{r}47 \\
\text { BGB }\end{array}$ & $\begin{array}{r}48 \\
\text { BPL }\end{array}$ & $\begin{array}{r}49 \\
\text { CDV }\end{array}$ & $\begin{array}{r}50 \\
\text { ESC }\end{array}$ & $\begin{array}{r}51 \\
\text { FCC }\end{array}$ & $\begin{array}{r}52 \\
\text { FEH }\end{array}$ & $\begin{array}{r}53 \\
\text { GYE }\end{array}$ & $\begin{array}{r}54 \\
\text { ILA }\end{array}$ & $\begin{array}{r}55 \\
\text { KEW }\end{array}$ & $\begin{array}{r}56 \\
\text { KIG }\end{array}$ \\
\hline Elasmobranch & 0 & 0 & 0 & 0 & 1 & 0 & 0 & 0 & 0 & 0 & 0 & 0 & 0 \\
\hline Roker & 2 & 0 & 0 & 0 & 0 & 0 & 0 & 0 & 0 & 0 & 0 & 0 & 0 \\
\hline Eel & 7 & 1 & 0 & 0 & 16 & 0 & 0 & 26 & 2 & 1 & 2 & 2 & 0 \\
\hline Conger eel & 0 & 0 & 1 & 0 & 0 & 0 & 0 & 0 & 0 & 0 & 0 & 0 & 0 \\
\hline Herring & 0 & 0 & 2 & 0 & 5 & 0 & 0 & 18 & 0 & 0 & 0 & 0 & 0 \\
\hline Sprat & 0 & 0 & 0 & 0 & 0 & 0 & 0 & 0 & 0 & 0 & 0 & 0 & 0 \\
\hline Shad & 0 & 0 & 0 & 0 & 0 & 0 & 0 & 0 & 0 & 5 & 0 & 0 & 0 \\
\hline Clupeid & 25 & 0 & 0 & + & 19 & 0 & 0 & 0 & 1 & 1 & 0 & 1 & 0 \\
\hline Salmonid & 0 & 1 & 0 & 0 & 0 & 0 & 0 & 0 & 0 & 0 & 2 & 0 & 0 \\
\hline Smelt & 3 & 0 & 0 & 0 & 0 & 0 & 0 & 0 & 0 & 0 & 3 & 0 & 0 \\
\hline Silver bream & 0 & 0 & 0 & 0 & 0 & 0 & 0 & 0 & 0 & 0 & 0 & 0 & 0 \\
\hline Barbel & 1 & 0 & 0 & 0 & 0 & 0 & 0 & 0 & 0 & 0 & 0 & 0 & 0 \\
\hline Gudgeon & 0 & 0 & 0 & 0 & 0 & 0 & 0 & 0 & 0 & 0 & 0 & 0 & 0 \\
\hline Dace & 0 & 0 & 0 & 0 & 0 & 0 & 0 & 0 & 1 & 0 & 0 & 0 & 0 \\
\hline Chub & 0 & 0 & 0 & 0 & 0 & 0 & 0 & 0 & 0 & 0 & 3 & 0 & 0 \\
\hline Roach & 0 & 0 & 0 & 0 & 0 & 0 & 0 & 0 & 0 & 0 & 0 & 0 & 0 \\
\hline Cyprinidae & 5 & 0 & 0 & 0 & 1 & 0 & 0 & 4 & 0 & $1 *$ & 2 & 0 & 0 \\
\hline Cod & 0 & 0 & 0 & 0 & 0 & 49 & 0 & 0 & 1 & 0 & 1 & 0 & 0 \\
\hline Haddock & 0 & 0 & 0 & 0 & 0 & 0 & 0 & 0 & 0 & 0 & 0 & 0 & 0 \\
\hline Whiting & 0 & 1 & 0 & 0 & 0 & 0 & 0 & 0 & 0 & 0 & 0 & 0 & 0 \\
\hline L Gadid & 5 & 0 & 0 & 0 & 0 & 0 & 0 & 0 & 0 & 0 & 0 & 0 & 0 \\
\hline Gadidae & 0 & 0 & 0 & + & 5 & 0 & 0 & 1 & 0 & 0 & 1 & 0 & 0 \\
\hline Ling & 0 & 0 & 0 & 0 & 0 & 0 & 0 & 0 & 0 & 0 & 0 & 0 & 0 \\
\hline Sandsmelt & 0 & 0 & 0 & 0 & 0 & 0 & 0 & 0 & 0 & 0 & 0 & 0 & 0 \\
\hline Stickleback & 0 & 0 & 0 & 0 & 0 & 0 & 0 & 0 & 0 & 0 & 0 & 0 & 0 \\
\hline Bass & 0 & 0 & 0 & 0 & 0 & 0 & 0 & 0 & 0 & 0 & 0 & 0 & 0 \\
\hline Perch & 0 & 0 & 0 & 0 & 0 & 0 & 0 & 0 & 0 & 0 & 0 & 0 & 0 \\
\hline Black s bream & 0 & 0 & 0 & 0 & 0 & 0 & 0 & 0 & 0 & 0 & 0 & 0 & 0 \\
\hline Red sea bream & 0 & 0 & 0 & 0 & 0 & 0 & 0 & 0 & 0 & 0 & 0 & 0 & 0 \\
\hline Sparidae & 0 & 1 & 0 & 0 & 0 & 0 & 0 & 0 & 0 & 0 & 0 & 0 & 0 \\
\hline Thick $1 \mathrm{~g}$ mullet & 0 & 0 & 0 & 0 & 0 & 0 & 0 & 0 & 0 & 0 & 1 & 0 & 0 \\
\hline Mugilidae & 0 & 0 & 0 & 0 & 0 & 0 & 1 & 0 & 0 & 0 & 0 & 0 & 0 \\
\hline Labridae & 0 & 0 & 0 & 0 & 0 & 0 & 0 & 1 & 0 & 0 & 0 & 0 & 0 \\
\hline Sandeel & 0 & 0 & 0 & 0 & 0 & 0 & 0 & 0 & 0 & 0 & 0 & 0 & 0 \\
\hline Mackerel & 6 & 1 & 1 & 0 & 0 & 1 & 0 & 0 & 0 & 0 & 0 & 0 & 0 \\
\hline Turbot & 0 & 0 & 0 & 0 & 0 & 0 & 0 & 0 & 0 & 0 & 0 & 0 & 0 \\
\hline Plaice & 0 & 0 & 0 & 0 & 1 & 0 & 0 & 0 & 0 & 0 & 0 & 0 & 0 \\
\hline Flounder & 0 & 0 & 0 & 0 & 0 & 0 & 0 & 0 & 0 & 0 & 0 & 0 & 0 \\
\hline Plaice/Flounder & 6 & 7 & 2 & 0 & 7 & 0 & 0 & 3 & 1 & 8 & 2 & 6 & 11 \\
\hline Flatfish indet & 0 & 1 & 0 & 0 & 0 & 0 & 0 & 0 & 0 & 0 & 0 & 0 & 0 \\
\hline Total & 60 & 13 & 6 & + & 55 & 50 & 1 & 53 & 6 & 16 & 17 & 9 & 11 \\
\hline Occ/40 sp & 9 & 7 & 4 & 2 & 8 & 2 & 1 & 6 & 5 & 5 & 9 & 3 & 1 \\
\hline
\end{tabular}




\begin{tabular}{|c|c|c|c|c|c|c|c|c|c|c|c|c|c|c|}
\hline $\begin{array}{r}\mathbf{5 7} \\
\text { KWS }\end{array}$ & $\begin{array}{r}58 \\
\text { LCT }\end{array}$ & $\begin{array}{r}59 \\
\text { MFI }\end{array}$ & $\begin{array}{r}60 \\
\text { MRG }\end{array}$ & $\begin{array}{r}61 \\
\text { NEG }\end{array}$ & $\begin{array}{r}62 \\
\text { NHG }\end{array}$ & $\begin{array}{r}63 \\
\text { ONE }\end{array}$ & $\begin{array}{r}64 \\
\text { PDN }\end{array}$ & $\begin{array}{r}65 \\
\text { PEN }\end{array}$ & $\begin{array}{r}66 \\
\text { RAG }\end{array}$ & $\begin{array}{r}67 \\
\text { SM }\end{array}$ & $\begin{array}{r}68 \\
\text { TR }\end{array}$ & $\begin{array}{r}69 \\
\text { VAL }\end{array}$ & total & $\begin{array}{r}\text { occ } / 26 \\
\text { sites }\end{array}$ \\
\hline 0 & 0 & 0 & 0 & 0 & 2 & 1 & 0 & 0 & 0 & 0 & 0 & 0 & 4 & 3 \\
\hline 0 & 0 & 0 & 0 & 0 & 0 & 0 & 0 & 0 & 0 & 0 & 0 & 0 & 2 & 1 \\
\hline 3 & 2 & 108 & 1 & 17 & 4 & 22 & 0 & 0 & 4 & 0 & 0 & 0 & 218 & 16 \\
\hline 0 & 0 & 0 & 0 & 0 & 0 & 0 & 0 & 0 & 0 & 0 & 0 & 0 & 1 & 1 \\
\hline 1 & 0 & 4 & 0 & 0 & 0 & 1 & 0 & + & 2 & 0 & 0 & 0 & $33+$ & 8 \\
\hline 0 & 0 & 0 & 0 & 0 & 0 & 0 & 0 & + & 56 & 0 & 2 & 0 & $58+$ & 3 \\
\hline 0 & 0 & 0 & 0 & 0 & 0 & 0 & 0 & 0 & 0 & 0 & 0 & 0 & 5 & 1 \\
\hline 0 & 0 & 53 & 8 & 12 & 16 & 24 & 0 & 0 & $1+$ & 1 & 0 & 0 & $162+$ & 13 \\
\hline 7 & 0 & 47 & 0 & 0 & 0 & 0 & 0 & 0 & 0 & 0 & 0 & 0 & 57 & 4 \\
\hline 4 & 0 & 126 & 0 & 0 & 0 & 2 & 0 & 0 & $230+$ & 0 & 0 & 0 & $368+$ & 6 \\
\hline 0 & 0 & 7 & 0 & 0 & 0 & 0 & 0 & 0 & 0 & 0 & 0 & 0 & 7 & 1 \\
\hline 0 & 0 & 3 & 0 & 0 & 0 & 0 & 0 & 0 & 0 & 0 & 0 & 0 & 4 & 2 \\
\hline 0 & 0 & 11 & 0 & 0 & 0 & 0 & 0 & 0 & 0 & 0 & 0 & 0 & 11 & 1 \\
\hline 0 & 0 & 20 & 0 & 0 & 0 & 0 & 0 & 0 & 0 & 0 & 0 & 0 & 21 & 2 \\
\hline 0 & 0 & 11 & 0 & 0 & 0 & 0 & 0 & 0 & 3 & 0 & 0 & 0 & 17 & 3 \\
\hline 2 & 0 & 34 & 0 & 0 & 0 & 0 & 0 & 0 & 0 & 0 & 0 & 0 & 36 & 2 \\
\hline 9 & 0 & 474 & 0 & 4 & 0 & 32 & 0 & 0 & 0 & 0 & 0 & 0 & $532 *$ & 9 \\
\hline 1 & 0 & 0 & 0 & 1 & 0 & 3 & 0 & 0 & 0 & 0 & 1 & 0 & 57 & 7 \\
\hline 0 & 0 & 2 & 0 & 1 & 0 & 0 & 0 & 0 & 0 & 0 & 0 & 0 & 3 & 2 \\
\hline 2 & 0 & 0 & 0 & 2 & 1 & 0 & 0 & 0 & 1 & 0 & 0 & 0 & 7 & 5 \\
\hline 6 & 0 & 0 & 0 & 1 & 0 & 0 & 0 & 0 & 0 & 0 & 0 & 0 & 12 & 3 \\
\hline 7 & 0 & 0 & 2 & 7 & 2 & 10 & 0 & 0 & 0 & 0 & 1 & 0 & $36+$ & 10 \\
\hline 0 & 0 & 0 & 0 & 0 & 0 & 0 & 0 & 0 & 0 & 1 & 0 & 0 & 1 & 1 \\
\hline 0 & 0 & 0 & 0 & 0 & 0 & 0 & 0 & 0 & + & 0 & 0 & 0 & + & 1 \\
\hline 0 & 0 & 0 & 0 & 0 & 0 & 0 & 0 & 0 & + & 0 & 0 & 0 & + & 1 \\
\hline 0 & 0 & 20 & 0 & 0 & 0 & 0 & 0 & + & 0 & 0 & 0 & 0 & $20+$ & 2 \\
\hline 0 & 0 & 11 & 0 & 0 & 0 & 0 & 0 & 0 & 0 & 0 & 1 & 0 & 12 & 2 \\
\hline 0 & 0 & 0 & 0 & 0 & 0 & 0 & 0 & 0 & 0 & 1 & 1 & 0 & 2 & 2 \\
\hline 0 & + & 0 & 0 & 0 & 0 & 0 & 0 & 0 & 0 & 0 & 0 & 0 & + & 1 \\
\hline 0 & 0 & 0 & 0 & 0 & 0 & 0 & 0 & 0 & 0 & 0 & 0 & 0 & 1 & 1 \\
\hline 0 & 0 & 0 & 0 & 0 & 0 & 0 & 0 & 0 & 0 & 0 & 0 & 0 & 1 & 1 \\
\hline 1 & 0 & 6 & 0 & 0 & 0 & 3 & 0 & 0 & 0 & 0 & 0 & 0 & 11 & 4 \\
\hline 0 & 0 & 0 & 0 & 0 & 0 & 0 & 0 & 0 & 0 & 0 & 0 & 0 & 1 & 1 \\
\hline 0 & 0 & 0 & 0 & 0 & 0 & 0 & 0 & + & 0 & 0 & 0 & 0 & + & 1 \\
\hline 3 & 0 & 6 & 0 & 0 & 0 & 4 & 0 & 0 & 0 & 0 & 0 & 0 & 22 & 7 \\
\hline 0 & 0 & 10 & 0 & 0 & 0 & 0 & 0 & 0 & 0 & 0 & 0 & 0 & 10 & 1 \\
\hline 0 & 0 & 2 & 0 & 0 & 0 & 0 & 0 & 0 & 0 & 0 & 0 & 0 & 3 & 2 \\
\hline 0 & 0 & 10 & 0 & 0 & 0 & 0 & 0 & + & 0 & 0 & 0 & 0 & $10+$ & 2 \\
\hline 16 & 0 & 261 & 5 & 4 & 0 & 60 & 0 & 0 & + & 0 & 0 & 0 & $399+$ & 16 \\
\hline 0 & 0 & 0 & 0 & 0 & 0 & 0 & 1 & 0 & 4 & 0 & 0 & 1 & 7 & 4 \\
\hline 62 & $2+$ & 1226 & 16 & 49 & 25 & 162 & 1 & + & 301+ & 3 & 6 & 1 & $2151+*$ & \\
\hline 13 & 2 & 21 & 4 & 9 & 5 & 11 & 1 & 5 & 11 & 3 & 5 & 1 & & \\
\hline
\end{tabular}




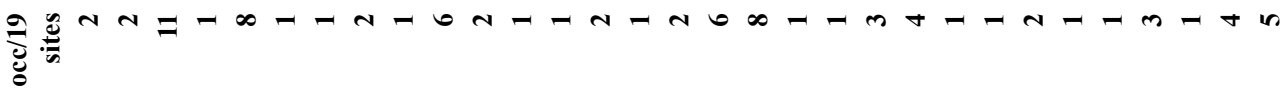

章

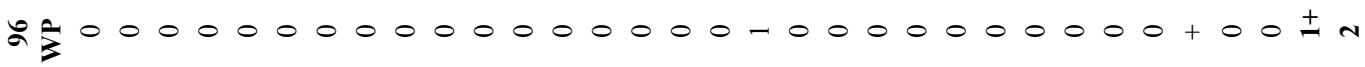
光券 İ

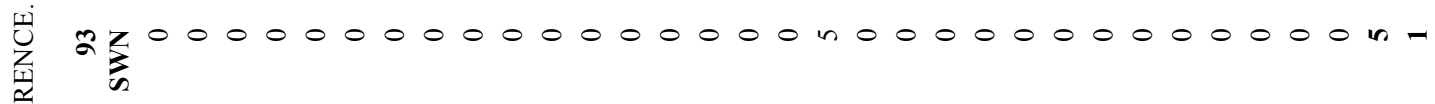
ลั

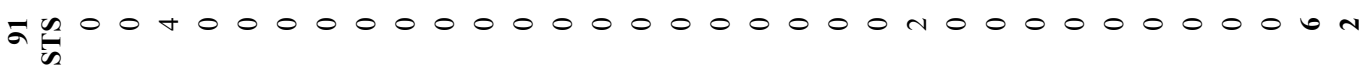

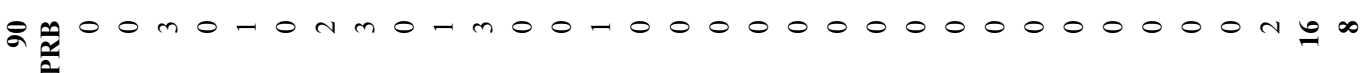
क

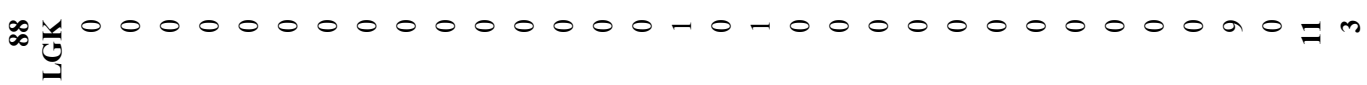
$\hat{D}_{\mathrm{A}} 00000000000000000-0000000000000-1$ ¿I్

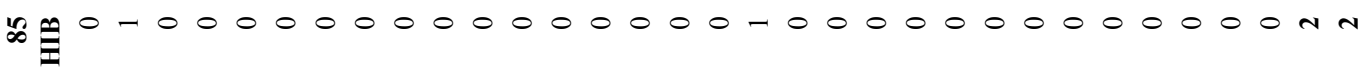
मॄ m-

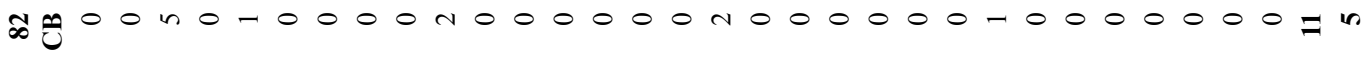
क

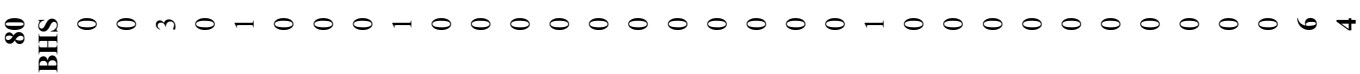
會 $000000000000000000000000-1000000-1$

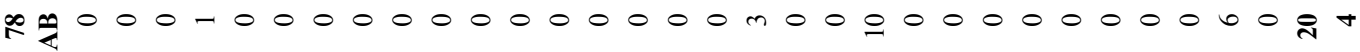

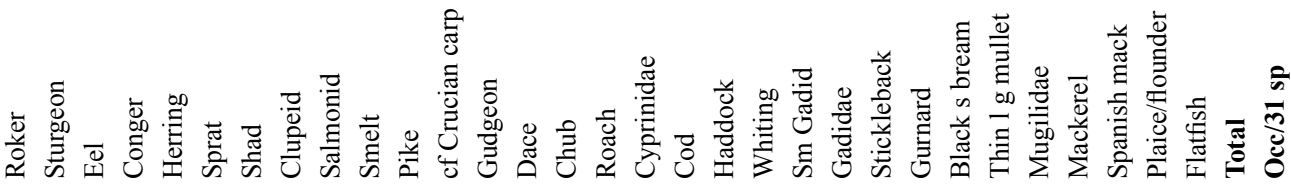


TABLE 10. SOUTH/SOUTH-WEST; THE FISH FROM 13 SITES BY NISP TOTAL AND OCCURRENCE.

\begin{tabular}{|c|c|c|c|c|c|c|c|c|c|c|c|c|c|c|c|c|}
\hline Site no. \& site & $\begin{array}{r}97 \\
\text { Dor }\end{array}$ & $\begin{array}{r}98 \\
\text { Dor }\end{array}$ & $\begin{array}{r}99 \\
\text { Exe }\end{array}$ & $\begin{array}{l}100 \\
\text { Fig }\end{array}$ & $\begin{array}{r}101 \\
\text { Ilch }\end{array}$ & $\begin{array}{r}102 \\
\text { Mad }\end{array}$ & $\begin{array}{r}103 \\
\text { New }\end{array}$ & $\begin{array}{r}104 \\
\text { Owe }\end{array}$ & $\begin{array}{r}105 \\
\text { Rop }\end{array}$ & $\begin{array}{r}106 \\
\text { Sci }\end{array}$ & $\begin{array}{r}107 \\
\text { Sci }\end{array}$ & $\begin{array}{l}108 \\
\text { Ule }\end{array}$ & $\begin{array}{r}109 \\
\text { Wad }\end{array}$ & nisp tl & & $\begin{array}{r}\text { occ/ } \\
13 \text { sites }\end{array}$ \\
\hline Elasmo & 0 & 0 & 0 & 0 & 0 & 0 & 0 & 0 & 0 & 1 & 0 & 0 & 0 & 1 & & \\
\hline Eel & 696 & 1 & 0 & 4 & 8 & 2 & 0 & + & 0 & 0 & + & 21 & 0 & 732 & + & \\
\hline Conger eel & 0 & 10 & 1 & 0 & 0 & 0 & 0 & 0 & 0 & 2 & 0 & 0 & 0 & 13 & & \\
\hline Salmonid & 0 & 2 & 4 & 0 & 0 & 0 & 0 & 0 & 0 & 0 & 0 & 50 & 0 & 56 & & \\
\hline Cyprinidae & 81 & 0 & 0 & 0 & 4 & 0 & 0 & 0 & 0 & 0 & 0 & 0 & 0 & 85 & & \\
\hline Angler & 0 & 0 & 0 & 0 & 0 & 0 & 1 & 0 & 0 & 0 & 0 & 0 & 0 & 1 & & \\
\hline Whiting & 0 & 0 & 3 & 0 & 0 & 0 & 0 & 0 & 0 & 5 & + & 0 & 0 & $8-$ & + & \\
\hline Pollack & 0 & 0 & 0 & 0 & 0 & 0 & 0 & 0 & 0 & 1 & + & 0 & 0 & 1 & + & \\
\hline Gadidae & 0 & 5 & 1 & 0 & 0 & 0 & 0 & 0 & 0 & 0 & 0 & 0 & + & 6 & + & \\
\hline Ling & 0 & 0 & 0 & 0 & 0 & 0 & 0 & 0 & 0 & 0 & + & 0 & 0 & + & & \\
\hline Hake & 0 & 0 & 5 & 0 & 0 & 0 & 0 & 0 & 0 & 0 & 0 & 0 & 0 & 5 & & \\
\hline John Dory & 0 & 0 & 0 & 0 & 0 & 0 & 0 & 0 & 0 & 0 & + & 0 & 0 & + & & \\
\hline Gurnard & 0 & 1 & 1 & 0 & 0 & 0 & 0 & 0 & 0 & 0 & 0 & 0 & 0 & 2 & & \\
\hline Perch & 0 & 0 & 0 & 0 & $*$ & 0 & 0 & 0 & 0 & 0 & 0 & 3 & 0 & 3 & $*$ & \\
\hline Bass & 0 & 268 & 4 & 0 & 0 & 0 & 0 & 0 & 0 & 0 & 0 & 2 & + & 274 & + & \\
\hline Scad & 0 & 10 & 0 & 0 & 0 & 0 & 0 & 0 & 0 & 0 & 0 & 1 & 0 & 11 & & \\
\hline Black sea bream & 0 & 0 & 0 & 0 & 0 & 0 & 0 & 0 & 0 & 1 & 0 & 0 & 0 & 1 & & \\
\hline Red sea bream & 0 & 0 & 0 & 0 & 0 & 0 & 0 & 0 & 0 & 1 & 0 & 9 & 0 & 10 & & \\
\hline Gilthead & 0 & 0 & 0 & 0 & 0 & 0 & 0 & 2 & 0 & 1 & 0 & 0 & 0 & 3 & & \\
\hline Sparidae & 9 & 45 & 2 & 0 & 1 & 0 & 0 & 0 & 0 & 0 & 0 & 0 & 0 & 57 & & \\
\hline Mugilidae & 0 & 56 & 0 & 0 & 0 & 0 & 0 & 0 & 0 & 0 & + & 2 & 0 & 58 & + & \\
\hline Cuckoo wrasse & 0 & 0 & 0 & 0 & 0 & 0 & 1 & 0 & 0 & 0 & + & 0 & 0 & 1 & + & \\
\hline Ballan wrasse & 0 & 0 & 0 & 0 & 0 & 0 & 8 & 0 & 1 & 8 & + & 0 & 0 & 17 & + & \\
\hline Labridae & 2 & 103 & 1 & 0 & 0 & 0 & 7 & 0 & 0 & 16 & 0 & 0 & + & 129 & + & \\
\hline Mackerel & 0 & 0 & 0 & 0 & 0 & 0 & 0 & 0 & 0 & 2 & 0 & 0 & 0 & 2 & & \\
\hline Turbot & 0 & 0 & 1 & 0 & 0 & 0 & 0 & 0 & 0 & 0 & 0 & 0 & 0 & 1 & & \\
\hline Plaice & 0 & 0 & 0 & 0 & 0 & 0 & 0 & 0 & 0 & 0 & + & 3 & 0 & 3 & + & \\
\hline Flounder & 0 & 0 & 0 & 0 & 0 & 0 & 0 & 0 & 0 & 0 & 0 & 8 & 0 & 8 & & \\
\hline Plaice/flounder & 0 & 0 & 0 & 0 & 1 & 0 & 0 & 0 & 0 & 0 & 0 & 21 & 0 & 22 & & \\
\hline Flatfish & 3 & 21 & 0 & 0 & 0 & 0 & 0 & 0 & 0 & 0 & 0 & 0 & 0 & 24 & & \\
\hline Total & 791 & 522 & 23 & 4 & $14 *$ & 2 & 17 & $2+$ & 1 & 38 & + & 120 & + & 1534 & & \\
\hline Occ/30 sp & 5 & 11 & 10 & 1 & 5 & 1 & 4 & 2 & 1 & 10 & 9 & 10 & 3 & & & \\
\hline
\end{tabular}




\section{ACKNOWLEDGEMENTS}

I would like to thank the following people for sending reports, answering endless queries, and allowing access to unpublished data: Enid Allison, Philip Armitage, Polydora Baker, Bruno Barber, James Barrett, Tønnes Bekker-Nielsen, Martin Bell, Stuart Cakebread, Ruby Ceron-Carrasco, Jennie Coy, Philip Crummy, Keith Dobney, Julie Gardiner, Sheila Hamilton-Dyer, Claire Ingrem, Claire Jones, James Kettle, Tony King, Martin Locker, Ros Niblett, Becky Nicholson, Terry O'Connor, Martin Papworth, Brian Philp, Liz Popescu, James Rackham, Kevin Rielly, Jenny Sample, Dale Serjeantson, Sue Stallibrass, Ian Smith, Naomi Sykes, Wim van Neer, and two referees for their helpful and constructive comments.

\section{Menton, France \\ galocker@cegetel.net}

This paper is published with the aid of a grant from the Council for British Archaeology

\section{BIBLIOGRAPHY}

Alcock, J. 2001: Food in Roman Britain, Stroud

Armitage, P.L. 2000a: Fish from Long Lane. LGK99, unpub. report for PreConstruct Archaeology

Armitage, P.L. 2000b: Fish from Southwark Cathedral MTA99, unpub. report for PreConstruct Archaeology

Armitage, P.L. 2002a: Fish from the New Wolfson Wing BHB00, unpub. report for PreConstruct Archaeology Armitage, P.L. 2002b: Fish from Swan Street SWN98, unpub. report for PreConstruct Archaeology

Armitage, P.L. 2005a: Fish from the Babe Ruth Site HGA02, unpub. report for PreConstruct Archaeology

Armitage, P.L. 2005b: Fish from Tobacco Dock TOC02, unpub. report for PreConstruct Archaeology

Ayton, W. 1998: Salmon Fisheries in England and Wales, Atlantic Salmon Trust, Pitlochry

Barber, B., and Bowsher, D. 2000: The Eastern Cemetery of Roman London: Excavations 1983-90, MoLAS Monograph 4, London (K. Rielly p. 73)

Barrett, J., Locker, A., and Roberts, C. 2004: 'The origins of intensive marine fishing in Medieval Europe: the English evidence', Proceedings of the Royal Society of London B. 04PB0328, 1-5

Bateman, N., and Locker, A. 1982: 'The sauce of the Thames', The London Archaeologist Vol. 4, No. 8, 204-7

Bekker-Nielsen, T. 2002a: 'Fish in the ancient economy', in K. Ascani (ed.), Ancient History Matters. Studies Presented to Jeris Erik Skydsgaard on his Seventieth Birthday, Analecta Romana Instituti Danici, Supp. 30, Rome, 29-37

Bekker-Nielsen, T. 2002b: 'Nets, boats and fishing in the Roman World', Classica et Mediaevalia 53, 215-33

Buckland, P. 1976: 'The environmental evidence from the Church Street Roman sewer system', in The Archaeology of York. The Past Environment of York 14 (1), York, 1-44

Campbell, J. (ed.) 1982: The Anglo Saxons, London

Ceron-Carrasco, R. 2002: The Fish Remains from Inveresk, unpub. report for AOC Archaeology, Edinburgh

Coy, J. 1987: 'Birds and fish', in P.J. Woodward, Romano-British Industries in Purbeck. Excavations at Ower and Rope Lake, Dorset Nat. Hist. Arch. Soc. Monograph 6, Dorchester, 114, 117, 178

Curtis, R.I. 1991: Garum and Salsamenta. Production and Commerce in Materia Medica, Leiden

Davies, R. 1971: 'The Roman military diet', Britannia 2, 122-42

Desse-Berset, N., and Desse, J. 2000: 'Salsamenta, garum et autres préparations de poissons', MEFRA $112,73-9$

Dobney, K., and Ervynck, A. 2006: 'To fish or not to fish? Evidence for the possible avoidance of fish consumption during the Iron Age around the North Sea', in C. Hazelgrove and T. Moore (eds), The Later Iron Age in Britain and Beyond, Oxford, 403-18

Ejstrud, B. 2005: 'Size matters: estimating trade of wine, oil and fish-sauce from amphorae in the first century AD', in T. Bekker-Nielsen (ed.), Ancient Fishing and Fish Processing in the Black Sea Region, Aarhus 
Enghoff, I. 2000: 'Fishing in the Southern North Sea region from the $1^{\text {st }}$ to the $16^{\text {th }}$ century AD: evidence from fish bones', Archaeofauna 9, 59-132

Ervynck, A. 1997: Review of K.M. Dobney, S.D. Jacques and B.G. Irving, Of Butchers and Breeds: Report on Vertebrate Remains from Various Sites in Lincoln in International Journal of Osteoarchaeology 7 , $252-3$

Ervynck, A., van Neer, W., Huster-Plogmannn, H., and Schibler, J. 2003: 'Beyond affluence: the zooarchaeology of luxury', World Archaeology 34(3), 428-41

Flower, B., and Rosenbaum, E. 1980: The Roman Cookery Book. A Critical Translation of The Art of Cookery by Apicius, London

Forster, E.S., and Heffner, A.M. 1968: Columella.II. De Re Rustica, Loeb Classical Library. No. 407, London

Fox, H. 2001: The Evolution of a Fishing Village: Landscape and Society along the South Devon Coast, 1086-1550, Leicester Explorations in Local History 1, Oxford

Hamilton-Dyer, S. 1993a: 'The sieved material and the fish remains', in R. Smith, Excavations at County Hall, Colliton Park, Dorchester, 1988, Wessex Archaeology Report 4, Salisbury, 80-1

Hamilton-Dyer, S. 1993b: 'Fish remains', in P. Woodward, S. Davies and A. Graham (eds), Excavations at the Old Methodist Chapel and Greyhound Yard, Dorchester 1981-1984, Dorset Nat. Hist. Arch. Soc. Monograph 12, Dorchester, 345

Hamilton-Dyer, S. 1996: 'Animal bone', in J. McKinley and M. Heaton, 'An RB farmstead and associated burials at Maddington Farm, Shrewton', Wilts. Arch. \& Nat. Hist. Mag. 89, 63-5

Hamilton-Dyer, S. 1997: 'The animal bones', in M. Fulford et al., 'Silchester: excavations at the North Gate, on the North Walls and in the Northern Suburbs 1988 and 1991-3', Britannia 28, 131-5

Hamilton-Dyer, S. 1999: 'Animal bone', in J. McKinley, 'Further excavation of an Iron Age and RomanoBritish enclosed settlement at Figheldean, nr Netheravon', Wilts. Arch. \& Nat. Hist. Mag. 92, 25-7

Hamilton-Dyer, S. 2000: 'The fish remains', in M. Fulford and J. Timby, Late Iron Age and Roman Silchester. Excavations on the Site of the Forum-Basilica 1977, 1980-6, Britannia Monograph 15, London, 485

Hoffmann, R. 1995: 'Environmental change and the culture of common carp in Medieval Europe', in Guelph Ichthyology Reviews 3, Institute of Ichthyology, University of Guelph, Guelph, Ontario, Canada, $57-85$

Ingrem, C. 2000: The Animal Bone from Romano-British Deposits at Atlantic Road, Newquay, Cornwall, unpub. report for the Cornwall Archaeology Unit

Ingrem, C. 2004: The Fish Bones from Fishbourne Roman Palace, Sussex, unpub. report for Sussex Archaeological Society

Ingrem, C. 2006: 'Fish remains', in M. Fulford, A. Clarke and H. Eckardt, Life and Labour in Late Roman Silchester. Excavations in Insula IX since 1997, Britannia Monograph 22, London, 167-88, 183

Irving, B. 1996: 'Fish', in K. Dobney, S. Jacques and B. Irving, Of Butchers and Breeds: Report on the Vertebrate Remains from Various Sites in the City of Lincoln, Lincoln Archaeological Studies 5, Lincoln, 53-6

Jacques, D., Hall, A., Kenward, H., and Carrott, J. 2004: Technical Report: Plant, Invertebrate, and Fish Remains from Excavations at 25 Bridge Street, Chester, unpub. Palaeoecology Research Services 2004/46, 20-6

Jones, A.K.G. 1977: 'The fish bones', in M. Bell, 'Excavations at Bishopstone', Sussex Arch. Coll. 115, $284-5$

Jones, A.K.G. 1978: 'The fish remains', in G. Dennis, 1-7 St Thomas Street. Southwark Excavations 1972-4. Part II, Joint Publication No. 1 London Middlesex Arch. Soc. \& Surrey Arch. Soc., London, 414, 416

Jones, A.K.G. 1983: Fish and Amphibian Remains from North Shoebury, Essex, unpub. Ancient Monuments Laboratory Report 3892. English Heritage.

Jones, A.K.G. 1986: Fish Remains from Excavations at Canvey Island. Site 1. 1986, unpub. Ancient Monuments Laboratory Report 22/86. English Heritage.

Jones, A.K.G. 1988a: 'Fish bones from excavations in the cemetery of St Mary Bishophill Junior', in T. O'Connor (ed.), Bones from the General Accident Site, Tanner Row, The Archaeology of York, The Animal Bones. 15/2, York, 126-30

Jones, A.K.G. 1988b: 'Fish bones (199 Borough High Street)', in P. Hinton, Excavations in Southwark 1973-76, Lambeth 1973-9, Joint Publication No. 3 London Middlesex Arch. Soc. \& Surrey Arch. Soc., London, 431-3 
Jones, A.K.G. 1996: 'Fishes', in J. May, Dragonby. Report on the Excavation of an Iron Age and RomanoBritish Settlement in N. Lincs, Oxbow Monograph 61, Oxford, 164-5

Jones, A.K.G. 1997: 'Fishes', in E. Hostetter and T.N. Howe (eds), The Romano-British Villa at Castle Copse, Great Bedwyn, Indianopolis, 334-8

Jones, A.K.G. 2001: The Fish Remains from Dee House, Chester, unpub.

Jones, G.B.D., and Shotter, O.C.A. 1998: Roman Lancaster. Rescue Archaeology in a Historic City 1970-5, Briganta Monograph 1, Lancaster

King, A. 1999: 'Diet in the Roman World: a regional inter-site comparison of the mammal bones', JRA 12, 168-202

Lernau, O., Cotton, H., and Goren, Y. 1996: 'Salted fish and fish sauces from Masada. A preliminary report', Archaeofauna 5, 35-41

Liddle, J. 1988: The Fish. 2-5 Devonshire Square, London, unpub. MoLAS Archive report

Locker, A. no date: The Fish Bones from Hayling Island, unpub.

Locker, A. no date: The Fish from a Well at Beddington Roman Villa, unpub.

Locker, A. 1981: Chichester, Sussex (CH/77/CS ES 29). The Fish Bones, unpub. archive report

Locker, A. 1985: Castle Street, Carlisle: The Fish Remains, unpub. Ancient Monuments Laboratory Report 4510. English Heritage

Locker, A. 1986a: Canterbury: The Fish Remains from Marlowe Sites 1-1V, unpub. Ancient Monuments Laboratory Report 118/87. English Heritage

Locker, A. 1986b: Colchester, Gilberd School. The Fish Bones, unpub. Ancient Monuments Laboratory Report 4868. English Heritage

Locker, A. 1986c: Rangoon Street: The Fish Bones from Context 1238, unpub. MoLAS Archive Report

Locker, A. 1990: 'The fish bones', in D. Neal, A. Wardle and J. Hunn, Excavation of the Iron Age, Roman and Medieval Settlement at Gorhambury, St Albans, English Heritage Report 14, London, 212

Locker, A. 1991: The Fish Bones from Calverts Buildings, 15-23 Southwark St, London SE1, unpub. MoLAS Archive Report

Locker, A. 1992a: 'The fish bones', in P. Crummy, Culver Street, Colchester Archaeological Report 6, Colchester, 278-80

Locker, A. 1992b: The Fish Remains from Roman Deposits at Waterfront Sites, unpub. MoLAS Archive Report

Locker, A. 1992c: The Fish Bones from Billingsgate 1982, unpub. MoLAS Archive Report

Locker, A. 1992d: The Fish Remains from Roman Deposits in Waterfront Sites. Draft Paper, unpub. MoLAS Archive Report

Locker, A. 1993: The Fish from Godmanchester, unpub.

Locker, A. 1994: The Fish Bones from the Fleet Valley; Sites VAL 88 and PWB 88, unpub. MoLAS Archive Report

Locker, A. 1995: The Fish Bones from Fennings Wharf, unpub. MoLAS Archive Report

Locker, A. 1996: 'The fish bones', in P. Ashbee, 'Halangy Down, St Mary's, Isles of Scilly. Excavations 1964-1977', Cornish Archaeology 35 (issued 1999), 115, 118

Locker, A. 1997a: 'Appendix 9. Fish bones', in P. Barker, R. White, K. Pretty, H. Bird and M. Corbishley, The Baths Basilica Wroxeter. Excavations 1966-90, English Heritage Archaeological Report 8, London, $365-7$

Locker, A. 1997b: The Fish Bones from Great Yard, Ilchester, unpub.

Locker, A. 1998a: The Fish from Rectory Farm, West Deeping, Lincs., unpub. report for the Environmental Archaeology Consultancy

Locker, A. 1998b: The Fish Bones from Excavations at Elm Farm, nr Maldon, Essex, unpub. report for Essex County Council

Locker, A. 1998c: The Fish from LeFevre Road, Bow, unpub. report for the Environmental Archaeology Consultancy

Locker, A. 1998d: The Fish from Parnell Road, Bow, unpub. report for the Environmental Archaeology Consultancy

Locker, A. 2002: The Fish from Excavations at the Former Post Office, Head Street, Colchester, unpub. report for the Colchester Archaeological Trust

Locker, A. 2004: The Fish from Meppershall, Beds, LMB01, unpub. report for the Environmental Archaeology Consultancy 
Locker, A. 2006: 'Omega 3: Rents, Lent and Charity', Petit Propos Culinaire 80, Totnes, 93-121

Lubinski, P.M. 1996: 'Fish heads, an experiment in differential bone preservation in a salmonid fish', Journal of Archaeological Science 23, 175-81

Maitland, P., and Campbell, R. 1992: Freshwater Fishes, London

Matthews, J. 2001: The Celtic Shaman, London

Matthews, J. 2002: Celtic Totemic Animals, Glastonbury

Morales Muniz, A. 1993: 'Where are the tunas? Ancient Iberian fishing industries from an archaeozoological perspective', in A. Clason, S. Payne and H.-P. Uerpmann (eds), Skeletons in her Cupboard. Festschrift to Juliet Clutton-Brock, Oxbow Monograph 34, Oxford, 135-41

Murphy, P., Albarella, U., Germany, M., and Locker, A. 2000: 'Production, imports and status. Biological remains from a Late Roman farm at Great Holts Farm, Boreham, Essex, UK', Environmental Archaeology $5,35-48$

Museum of London Archaeological Service Oracle archive of City Sites

Nicholson, R. 1992: Fish Remains from Excavations at the Shires, Little Lane (A39) and St Peter's Lane ((A40), Leicester 1988, Ancient Monuments Laboratory Report 56/92, English Heritage

Nicholson, R. 1993a: The Fish Remains from Excavations at Ribchester, Lancashire, 1989-90, Ancient Monuments Laboratory Report 121/93, English Heritage

Nicholson, R. 1993b: The Fish Remains from Excavations at The Lanes, Carlisle, unpub. report, Environmental Archaeology Unit, University of York

Nicholson, R. 1995: 'Fish remains', in P. Andrews, Excavations at Redcastle Furze, Thetford, East Anglian Report 72, Dereham, 128-30

Nicholson, R. 1999: 'Fish remains', in A. Connor and R. Buckley, Roman and Medieval Occupation in Causeway Lane, Leicester. Excavations 1980 \& 1991, Leicester Archaeology Monograph 5, Leicester, 333-7

Nicholson, R., and Scott, S. 2004: 'The fish remains', in H. Dalwood and R. Edmonds, Excavations at Deansway, Worcester 1988-9. Romano-British Town to Late Medieval City, CBA Report 139, York, 515-19

O'Connor, T. 1988: Bones from the General Accident Site, The Archaeology of York. The Animal Bones $15 / 2$, York

Parfitt, S. 1995: 'Small vertebrates', in F. Aldsworth and D. Rudling, 'Excavations at Bignor Roman Villa, West Sussex 1985-90', Sussex Arch. Coll. 133, 173

Ratcliffe, J., and Straker, V. 1996: The Early Environment of Scilly, Cornwall Archaeological Unit

Ross, A. 1967: Pagan Celtic Britain, London

Rowsome, P., and Burch, M. 1992: Excavations at 17 Fish Street Hill and Monument Street, London EC3. (MF 187). Docklands Light Railway City Extension Archaeological Project, unpub. MoLAS Archive Report

Richards, M., and Hedges, R. 1998: 'Isotope analysis reveals variations in human diet at the Poundbury Camp cemetery site', Journal of Archaeological Science 25, 1247-52

Richmond, I. 1968: Hod Hill. Vol II. Excavations carried out between 1951 and 1958, London

Smith, P. 1993: 'Appendix 2: fish remains from Birdoswald', in K. Izard, The Animal Bones from Birdoswald, CAS site 420. Cumbria. 1986-1990, unpub. Ancient Monuments Laboratory Report 13/93. English Heritage

Starkey, D., Reid, C., and Ashcroft, N. 2000: England's Sea Fisheries. The Commercial Sea Fisheries of England and Wales since 1300, London

Stallibrass, S. 2002: 'Animal bones from Thornborough Farm', in P.R. Wilson, Cataractonium: Roman Catterick and its Hinterland. Excavations and Research, 1958-1997. Part II, CBA Research Report 129, York, 431-3

Toynbee, J.M.C. 1973: Animals in Roman Life and Art, London

Turk, F. 1984: 'A study of the vertebrate remains from May's Hill, St Martins', Cornish Studies II (for 1983), 69-80.

van Neer, W., and Ervynck, A. 2004: 'Remains of traded fish in archaeological sites: indicators of status or bulk food?', in S. Jones O'Day, W. van Neer and A. Ervynck (eds), Behaviour Behind Bones. The Zooarchaeology of Ritual, Religion, Status and Identity. Proceedings of the $9^{\text {th }}$ Conference of the International Council of Zooarchaeology, Durham, 2002, Oxford, 203-14

van Neer, W., Lernau, O., Friedman, P., Mumford, G., Poblome, J., and Waelkens, M. 2004: 'Fish remains from archaeological sites as indicators of former trade connections in the Eastern Mediterranean', Palaeorient. 30/1, 101-48 
van Neer, W., Wouters, W., Ervynck, A., and Maes, J. 2005: 'New evidence from a Roman context in Belgium for fish sauce produced locally in Northern Gaul', Archaeofauna 14, 171-82

Vissler, M. 1991: The Rituals of Dinner, London

Webster, G. 1964: 'Further investigations on the site of a Roman fort at Waddon Hill, Stoke Abbott 19602', Proc. Dorset Nat. Hist. \& Arch. Soc. 86, 144

Webster, G. 1979: 'Final report on the excavations of the Roman fort at Waddon Hill, Stoke Abbott 19639', Proc. Dorset Nat. Hist. \& Arch. Soc. 101, 90

Wheeler, A. 1974: 'Fish remains', in D. Thomas, Excavations at Billingsgate Buildings, Lower Thames Street, London, London Middlesex Arch. Soc. Special Paper 4, London, 161-2

Wheeler, A. 1978: Key to the Fishes of Northern Europe, London

Wheeler, A. 1979: The Tidal Thames, London

Wheeler, A. 1981: 'Fish bones', in C. Partridge, Skeleton Green. A Late Iron Age and Romano-British Site, Britannia Monograph 2, London, 242-3

Wheeler, A. 1984: 'Fish bones', in D. Miles (ed.), Archaeology at Barton Court Farm, Abingdon, Oxon., Oxford Archaeological Report 3; CBA Research Report 50, York (microfiche)

Wheeler, A. 1993: 'The fish', in A. Woodward and P. Leach, The Uley Shrines. Excavation of a Ritual Complex on West Hill, Uley, Gloucestershire 1977-9, English Heritage Archaeological Report 17, London, 264-5

White, J., and Tallboys, G. 2002: The Path through the Forest. A Druid Guidebook, Cambridge

Wilkinson, M. 1979: 'The fish remains', in M. Maltby, The Animal Bones from Exeter 1971-1975, Exeter Archaeological Report 2, Exeter, 74-81

Williamson, R. 1991: Salmon Fisheries in Scotland, Atlantic Salmon Trust, Pitlochry

Wilson, C.A. 1973: Food and Drink in Britain, London

Yule, B. 1989: 'Excavation at Winchester Palace, Southwark', The London Archaeologist Vol. 6. No. 2, 31-9

Yule, B. 2005: A Prestigious Roman Building Complex on the Southwark Waterfront: Excavations at Winchester Palace, London. 1983-90, MoLAS Monograph 23, London

Zeepat, R. 1988: 'Fishponds in Roman Britain', in M. Aston (ed.), Medieval Fish, Fisheries and Fishponds in England. Part I, BAR British Series 182 (1), Oxford, 17-26 